\title{
Petrology of the
}

Ultramafic and Gabbroic Rocks of the Brady Glacier Nickel-Copper Deposit, Fairweather Range, Southeastern Alaska

GEOLOGICALSURVEY PROFESSIONAL PAPER 1195

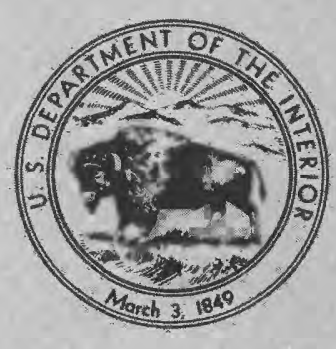




\section{Petrology of the}

\section{Ultramafic and Gabbroic Rocks of the Brady Glacier Nickel-Copper Deposit, Fairweather Range, Southeastern Alaska}

By GLEN R. HIMMELBERG and ROBERT A. LONEY

G E O L O G I C A L S U R V E Y P R O F E S S I O N A L P A P E R 1195

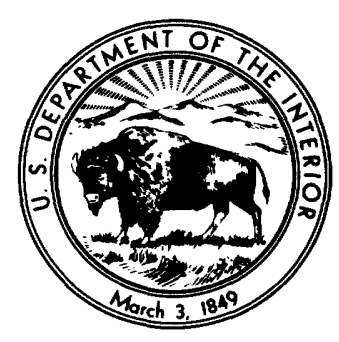




\section{UNITED STATES DEPARTMENT OF THE INTERIOR}

\section{JAMES G. WATT, Secretary}

\section{GEOLOGICAL SURVEY}

Doyle G. Frederick, Acting Director

Library of Congress Cataloging in Publication Data

Himmelberg, Glen R.

Petrology of the ultramafic and gabbroic rocks of the Brady Glacier nickel-copper deposit, Fairweather Range, southeastern Alaska

(Geological Survey Professional Paper 1195)

Bibliography: p. 24

Supt. of Docs. no.: I 19.16:1195

1. Rocks, Ultrabasic. 2. Gabbro-Alaska-Fairweather Range. 3. Ore-deposits-Alaska-Fairweather Range. 4. PetrologyAlaska-Fairweather Range. I. Loney, Robert Ahlberg, 1922- joint author. II. Title. III. Series: United States Geological Survey Professional Paper 1195.

For sale by the Superintendent of Documents, U.S. Government Printing Office Washington, D.C. 20402 


\section{CONTENTS}

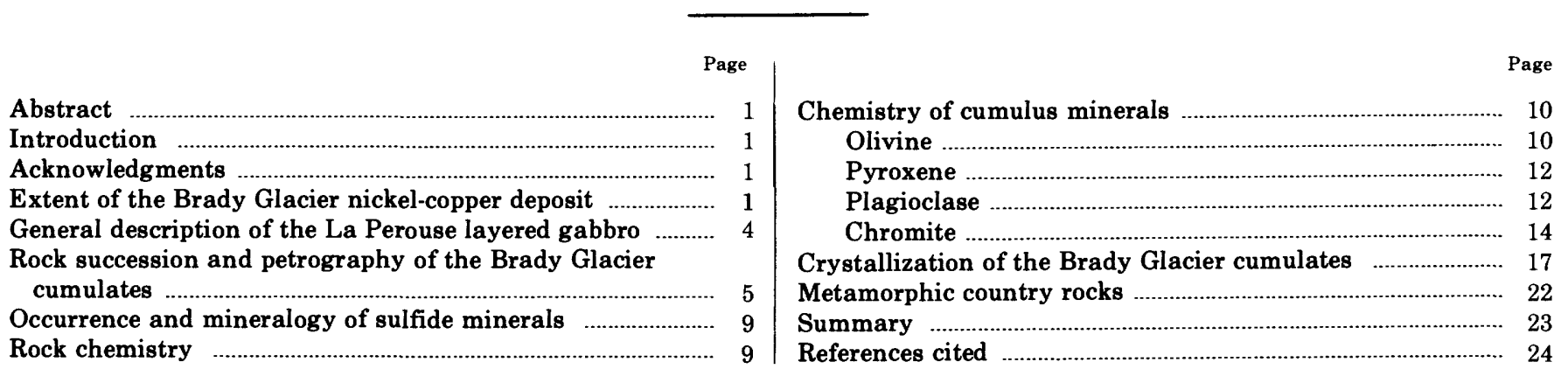

\section{ILLUSTRATIONS}

FIGURE 1. Index map showing location of major gabbro bodies in the Fairweather Range, Alaska

2. Map of La Perouse layered gabbro and surrounding country rocks showing location of Brady Glacier cumulates.

3. Map of the Brady Glacier cumulate area showing location of nunataks, drill holes, and cross sections

4-6. Generalized cross sections through the Brady Glacier cumulates:

4. Southwest-northeast cross section

5. Northwest-southeast cross section

6. North-south cross section

7-10. Core sections showing stratigraphic distribution and chemical composition of cumulus minerals, Brady Glacier cumulates:

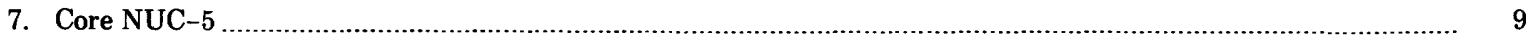

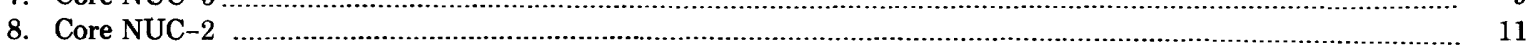

9. Core NUC-7

10. Core NUC-10

11-16. Graphs showing:

11. MgO variation of Brady Glacier cumulate rock samples …..................................................................

12. Variation of olivine composition in the olivine cumulate in the lower part of core NUC-5

13. Composition profiles across plagioclase grains

14. Variation of the cation ratios $\mathrm{Mg}$ to $\left(\mathrm{Mg}+\mathrm{Fe}^{+2}\right)$ and $\mathrm{Cr}$ to $(\mathrm{Cr}+\mathrm{Al})$ chromite in the Brady Glacier cumulates

15. Variation in $\mathrm{MnO}$ content of chromite in the Brady Glacier cumulates

16. Variation of $\mathrm{TiO}_{2}$ content of chromite in the Brady Glacier cumulates...

\section{TABLES}

TABLE 1. Chemical composition of Brady Glacier cumulate samples

2-6. Chemical composition and structural formulas of cumulus phases, Brady Glacier cumulates:

2. Olivine

3. Bronzite

4. Augite

5. Plagioclase

6. Chromite 


\section{METRIC-ENGLISH EQUIVALENTS}

Metric

1 Meter(m)

1 kilometer $(\mathrm{km})$

1 kilobar(kbar)

$1{ }^{\circ} \mathrm{C}$
U.S. Customary equivalent

$=\quad 3.281$ feet $(\mathrm{ft})$

$=0.6214 \mathrm{mile}(\mathrm{mi})$

$=987$ atmospheres (atm)

$=5 / 9\left({ }^{\circ} \mathrm{F}-32\right)$ 


\title{
PETROLOGY OF THE ULTRAMAFIC AND GABBROIC ROCKS OF THE BRADY GLACIER NICKEL-COPPER DEPOSIT, FAIRWEATHER RANGE, SOUTHEASTERN ALASKA
}

\author{
By Glen R. HimmelberG ${ }^{1}$ and ROBERT A. LONEY
}

\begin{abstract}
The basal cumulates of the La Perouse layered gabbro, the Brady Glacier cumulates, are the host rocks for the Brady Glacier nickel-copper deposit, Fairweather Range, southeastern Alaska. Major rock types of the Brady Glacier cumulates are olivinechromite cumulate, plagioclase-augite-olivine cumulate, and olivine-bronzite-chromite cumulate. The cumulates are interlayered on a scale of a few centimeters to hundreds of meters; the layers are not laterally continuous over large distances but are lenticular and wedge out in all directions. The layering seems to be draped over the metamorphic basement topography, which has considerable relief. Sulfide minerals are dominantly pyrrhotite, pentlandite, and chalcopyrite. Although disseminated sulfide minerals show no relation to stratigraphic position or rock type, massive sulfides tend to occur along boundaries between mafic and ultramafic layers. Textures indicate that the sulfide mineralization represents an immiscible sulfide melt.

Rock chemistry indicates that the ultramafic and gabbroic cumulates are related by differentiation. Cumulus-mineral compositions are olivine- $-\mathrm{Fo}_{86}$ to $\mathrm{Fo}_{71}$; plagioclase- $\mathrm{An}_{81}$ to $\mathrm{An}_{63}$; bronzite- $\mathrm{Ca}_{3} \mathrm{Mg}_{82} \mathrm{Fe}_{15}$ to $\mathrm{Ca}_{4} \mathrm{Mg}_{75} \mathrm{Fe}_{21}$; augite- $\mathrm{Ca}_{45} \mathrm{Mg}_{47} \mathrm{Fe}_{8}$ to $\mathrm{Ca}_{42}$ $\mathrm{Mg}_{48} \mathrm{Fe}_{10}$.

Spatial distribution of cumulate sequences suggests two orders of crystallization: (1) olivine, olivine + bronzite, olivine + bronzite + plagioclase, and (2) olivine, olivine + plagioclase, olivine + plagioclase + augite. The differences in crystallization sequence are believed to result from separate injections of magma of slightly different composition.
\end{abstract}

\section{INTRODUCTION}

Major nickel-copper sulfide deposits are associated with ultramafic and mafic rocks. Naldrett and Cabri (1976) have demonstrated the relations between composition of sulfide ore and the geochemistry of the host rocks. Their study showed that the major nickel-copper sulfide deposits are associated with tholeiitic or komatiitic rock types, the $\mathrm{Cu}$ to $(\mathrm{Cu}+\mathrm{Ni})$ ratio of the sulfide ore increasing with decreasing MgO content of the host rocks. Naldrett and Cabri pointed up the necessity of determining the nature of the igneous host rocks as well as the relations of the

${ }_{1}^{1}$ U.S. Geological Survey and Department of Geology, University of Missouri, Columbia, MO 65211. ore to the host rock. In this paper, we examine the rock succession, chemistry, and petrology of the basal rocks of the La Perouse layered gabbro that are the host rocks for nickel-copper sulfide deposits. The sulfide deposit of the La Perouse body is generally known as the Brady Glacier deposit (Brew and others, 1978), and the host rock cumulates are herein informally referred to as the Brady Glacier cumulates. The La Perouse gabbro intrusion was called the Crillon-La Perouse stock by Rossman (1963); for convenience in this report, it is called simply the $\mathrm{La}$ Perouse layered gabbro.

Rock classification and nomenclature used in this report is that recommended by the IUGS Subcommission on the Systematics of Igneous Rocks (1973); cumulus terminology is that of Wager and others (1960) and of Jackson (1967).

\section{ACKNOWLEDGMENTS}

We thank Newmont Exploration, Ltd. for generosity in making available to us the diamond-drill core and other materials from the company's Brady Glacier nickel-copper prospect. We especially acknowledge the cooperation and courtesy of Mr. Bryon S. Hardie, of Newmont Exploration, Ltd., Tucson, Ariz., and Mr. Earl Craig, of Dawn Mining Co., Ford, Wash., where the drill core was stored. Edward M. MacKevett, Jr., formerly of the U.S. Geological Survey, gave invaluable help in initiating the project.

\section{EXTENT OF THE BRADY GLACIER NICKEL-COPPER DEPOSIT}

The Brady Glacier nickel-copper deposit lies near the southeast margin of the La Perouse layered gabbro (figs. 1, 2), where, except for two-sometimes under light-snow conditions three-small nunataks, it is covered by the Brady Glacier. The deposit was 


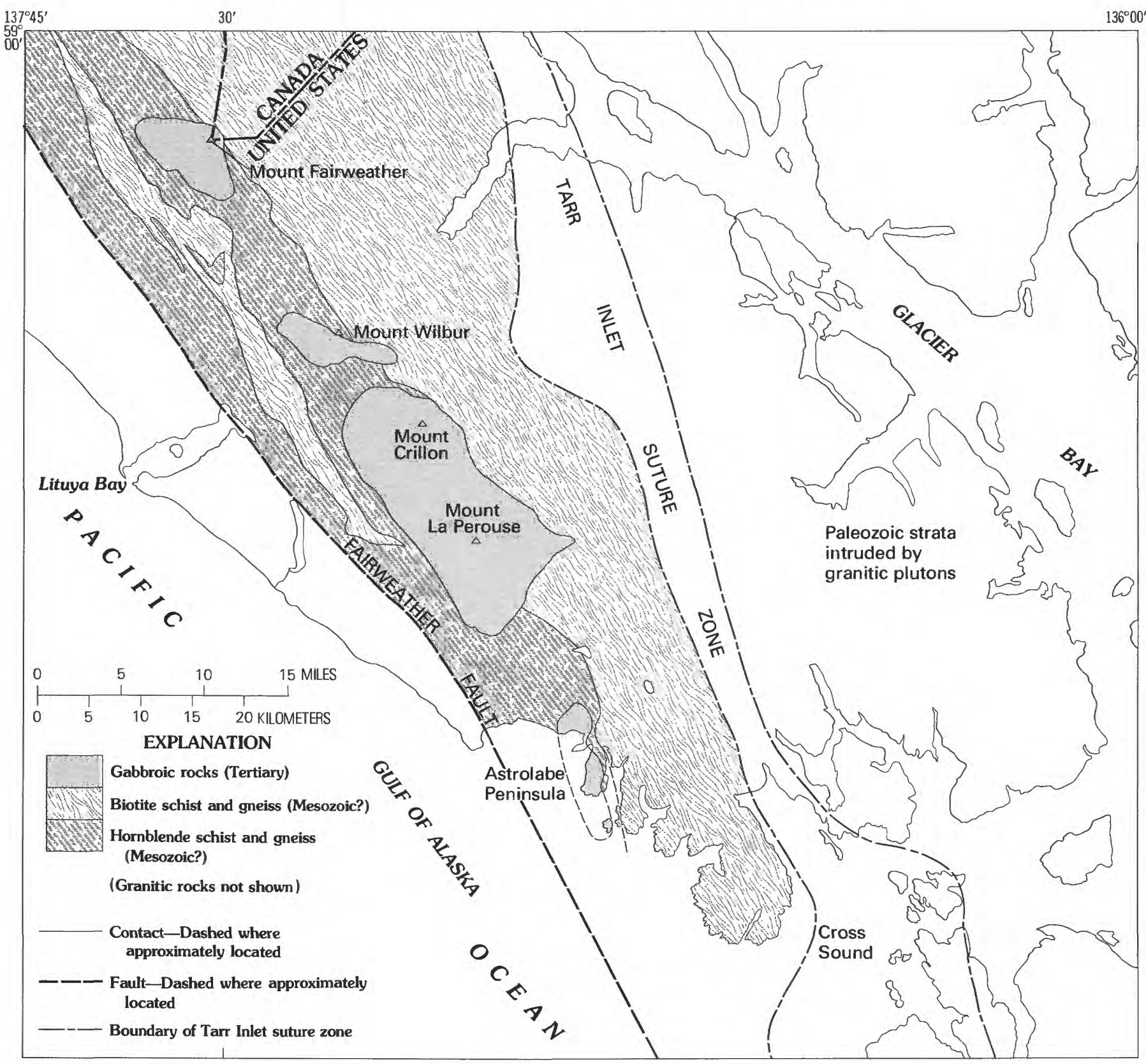

FIGURE 1.-Location of major gabbro bodies in the Fairweather Range, Alaska. Adapted from Brew and others (1978); location of Tarr Inlet suture zone from Brew and Morrell (1978, fig. 42).

discovered in 1958 by prospectors of the Fremont Mining Co.; by late 1959, the company had completed 32 diamond-drill holes (MacKevett and others, 1971, p. 81-82). In 1960, Newmont Exploration, Ltd. became manager of the property through a lease agreement with Fremont and during the years 1960 and 1961 drilled 14 additional diamond-drill holes. By the early 1970 's, 36 more holes had been drilled, bringing the total to 82 .

The areal extent of the drilling (fig. 3) was limited by glacial ice conditions and by the gabbro-schist contact rather than by systematic lateral decrease in sulfide mineralization (R. D. Ellett, 1975, cited in Brew and others, 1978). Further surface drilling to the northeast was prevented by thicker ice (greater than $320 \mathrm{~m}$ ); drilling to the west, by higher rates of ice flow. In these directions, then, the limits of the mineralization are unknown. The gabbro-schist contact south and east of the nunataks probably represents the main outer contact of the La Perouse gabbro intrusion; whereas the contact northwest of the nunataks may represent an isolated knob of 


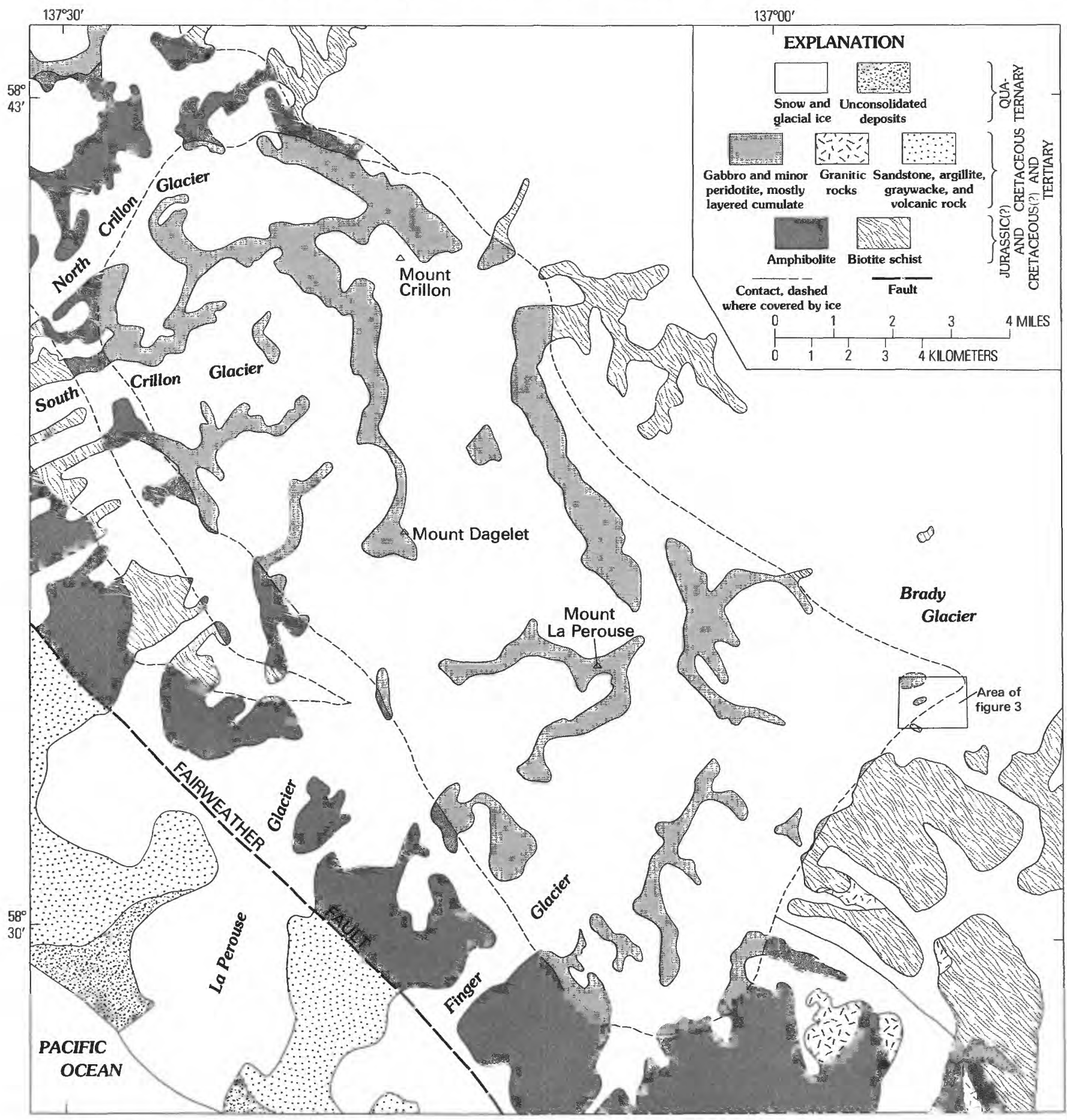

FIgURE 2.-La Perouse layered gabbro and surrounding country rocks. Rectangular box (area of fig. 3) shows location of the Brady Glacier cumulates. Map based on U.S. Geological Survey Mount Fairweather C-3, C-4, D-3, and D-4 quadrangles, $1: 63,360$.

schist basement within the periphery of the intrusion. In general, the stratigraphic units delineated by core data tend to parallel the schist contact which suggests the draping of layers over the basement topography.
In 1972, Newmont Exploration, Ltd., offered the U.S. Geological Survey the opportunity to study the cores. Key cores were logged and sampled at the company warehouse near Ford, Wash., in 1973 and 1975. During the summers of 1975,1976 , and 1977 , 


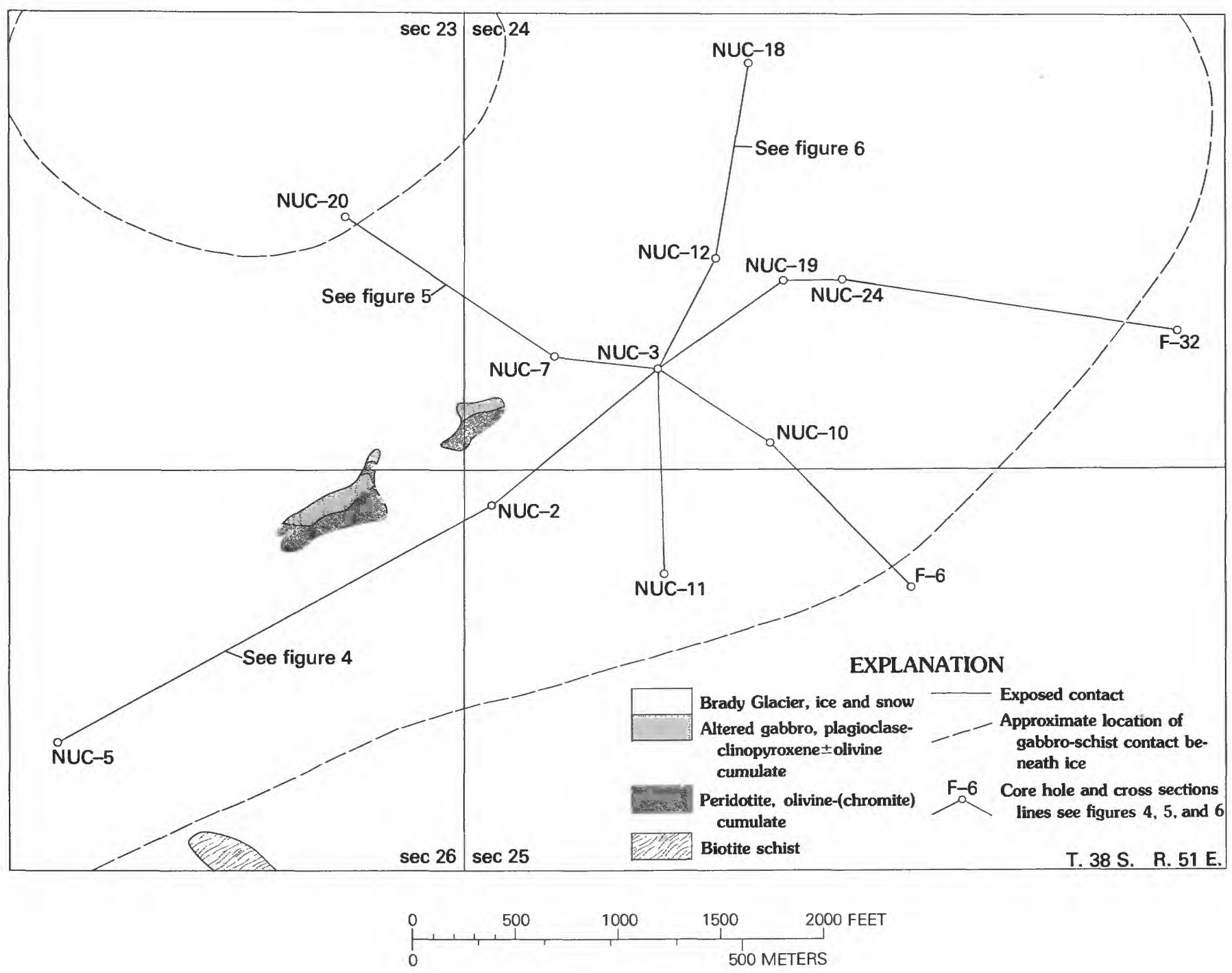

Figure 3.-Brady Glacier cumulate area showing location of nunataks, drill holes, and cross sections. Data on drill holes by courtesy Newmount Exploration, Ltd.; map based on U.S. Geological Survey Mount Fairweather C-3 quadrangle, 1:63,360.

field studies were carried out in the Brady Glacier area and in the main outcrop area of the La Perouse layered gabbro.

\section{GENERAL DESCRIPTION OF THE LA PEROUSE LAYERED GABBRO}

The La Perouse layered gabbro is the largest of several gabbro bodies exposed in the Fairweather Range, southeastern Alaska (fig. 1). Other gabbro bodies include the Fairweather body (Plafker and MacKevett, 1970) and the Mount Wilbur body (D. A. Brew, oral commun., 1977) to the north and the Astrolabe-DeLangle body to the south. Both the La Perouse and Astrolabe-DeLangle gabbros were reported on by Rossman (1963) and studied by
Himmelberg and Loney, but little is known about the Fairweather and the Mount Wilbur bodies.

The La Perouse layered gabbro underlies an area approximately 12 by $27 \mathrm{~km}$ and has an exposed thickness of about $6,000 \mathrm{~m}$ (fig. 2). The body was emplaced in the Tertiary into a sequence of biotite schists and amphibolites of probably Mesozoic age (Rossman, 1963; MacKevett and others, 1971). The dominant rock types are interlayered olivine gabbro and norite with lesser amounts of gabbronorite, troctolite, and rare anorthosite. Thin layers of ultramafic rocks occur throughout the sequence, but, except in the basal cumulates, are extremely rare. Layering and textural characteristics indicate that the body originated largely by cumulus processes. Layers range in thickness from centimeters to hun- 
dreds of meters. Although individual layers may be well defined by either phase contacts or ratio contacts (see photographs of layering in Rossman, 1963), there are no distinctive units that can be traced throughout the body and none that can be used as marker units across the rugged terrain. Most layers tend to fade or wedge out over relatively short distances. Distribution of cumulus minerals and the absence of any systematic variation in mineral composition relative to stratigraphic height (Rossman, 1963; Himmelberg, unpub. data, 1979) suggest multiple injections of magma rather than large volumes of magma crystallizing and differentiating. In these aspects, the La Perouse gabbro is similar to the Axelgold intrusion in British Columbia (Irvine, 1975a).

The base of the La Perouse intrusion is not exposed; but basal cumulates, the Brady Glacier cumulates, are exposed in two nunataks in the Brady Glacier southeast of the main body (fig. 2) and have been penetrated by drilling through the Brady Glacier in the vicinity of the nunataks. These basal cumulates are the host rocks for the nickel-copper sulfide deposit.

The age of the La Perouse intrusion is uncertain. Czamanske and his coworkers (1978) reported the following age-related isotopic data: ${ }^{87} \mathrm{Sr} /{ }^{86} \mathrm{Sr}$ range from 0.7041 to 0.7047 among plagioclase, olivine and pyroxene fractions; low rubidium content precludes rubidium-strontium dating. Conventional potassium-argon dates for plagioclase, hornblende, and clinopyroxene are discordant and range from 32 to $250 \mathrm{~m} . \mathrm{y}$. (million years); ${ }^{143} \mathrm{Nd} /{ }^{144} \mathrm{Nd}$ range only from 0.51293 to 0.51299 , although ${ }^{147} \mathrm{Sm} /{ }^{144} \mathrm{Nd}$ range from 0.128 to 0.293 for whole-rock, plagioclase, and pyroxene fractions. These samarium-neodymium isotopic ratios constrain the rock age to less than 100 $\mathrm{m} . \mathrm{y}$. if it is assumed that the samarium-neodymium systematics were not disturbed by nearby granitic intrusive activity 26-30 m.y. ago. Dating by the ${ }^{40} \mathrm{Ar} /{ }^{39} \mathrm{Ar}$ technique indicates an age as young as 30 m.y. (R. J. Fleck, oral commun., 1979), which suggests, along with the samarium-neodymium data, that the higher conventional potassium-argon ages result from excess argon.

By Naldrett and Cabri's classification of ultramafic and related rocks (1976), the La Perouse layered gabbro and sulfide deposit is most similar to the "large stratiformly layered complexes." The La Perouse gabbro differs from other stratiform bodies such as the Bushveld Complex, South Africa (Wager and Brown, 1968; Visser and von Gruenewaldt, 1970), Stillwater Complex, Montana (Hess, 1960; Jackson, 1961; Page, 1977), and Muskox intrusion
(Irvine and Smith, 1967) in two significant ways: (1) It was not emplaced in a nonorogenic cratonic area but rather near a major fault system into country rocks similar to an oceanic crust assemblage; (2) It shows no systematic relation between mineral chemical variation and stratigraphic height; this suggests multiple injection of magma with limited differentiation.

\section{ROCK SUCCESSION AND PETROGRAPHY OF THE BRADY GLACIER CUMULATES}

Though exposed in only a few small nunataks, the extent of the Brady Glacier cumulates under the Brady Glacier, and therefore the extent of the sulfide deposit, has been relatively well established by diamond-core drilling except to the north and west in the direction of the exposed La Perouse gabbro body. Ten drill cores were studied and sampled in detail to determine the rock succession, petrography, chemistry, and crystallization history of the Brady Glacier cumulates. The location of structurally important drill holes is shown in figure 3. About an equal number of drill cores were studied in less detail.

Cross sections constructed from core data, figures 4,5 , and 6 , illustrate the interlayering of major rock units. Slightly more layering detail is shown in individual core sections of figures 7 through 10 . The layers are distinguished on the basis of cumulus mineralogy only. A cumulate consists of cumulus grains that precipitated from the magma and settled to the floor of the magma chamber and postcumulus material that crystallized later in the places it now occupies in the magmatic sediment (Jackson, 1967). Identity of layers that result from the accumulation of cumulus minerals and in general reflect the crystallization sequence of the magma may be obscured if whole-rock mineralogy is utilized. In rocks of the same cumulus mineralogy, the postcumulus material may vary in kind and amount, laterally or vertically, within a single cumulate layer and from layer to layer. For example, a single olivinechromite cumulate layer may vary from a dunite to an olivine gabbro, depending on the amount of pos tcumulus plagioclase and clinopyroxene.

Individual layers range in thickness from a few centimeters to hundreds of meters; the phase contacts between layers are generally sharp, but some contacts between olivine cumulate and overlying plagioclase-augite-olivine cumulate appear gradational because of gradational increase in postcumulus plagioclase in the olivine cumulate before plagio- 


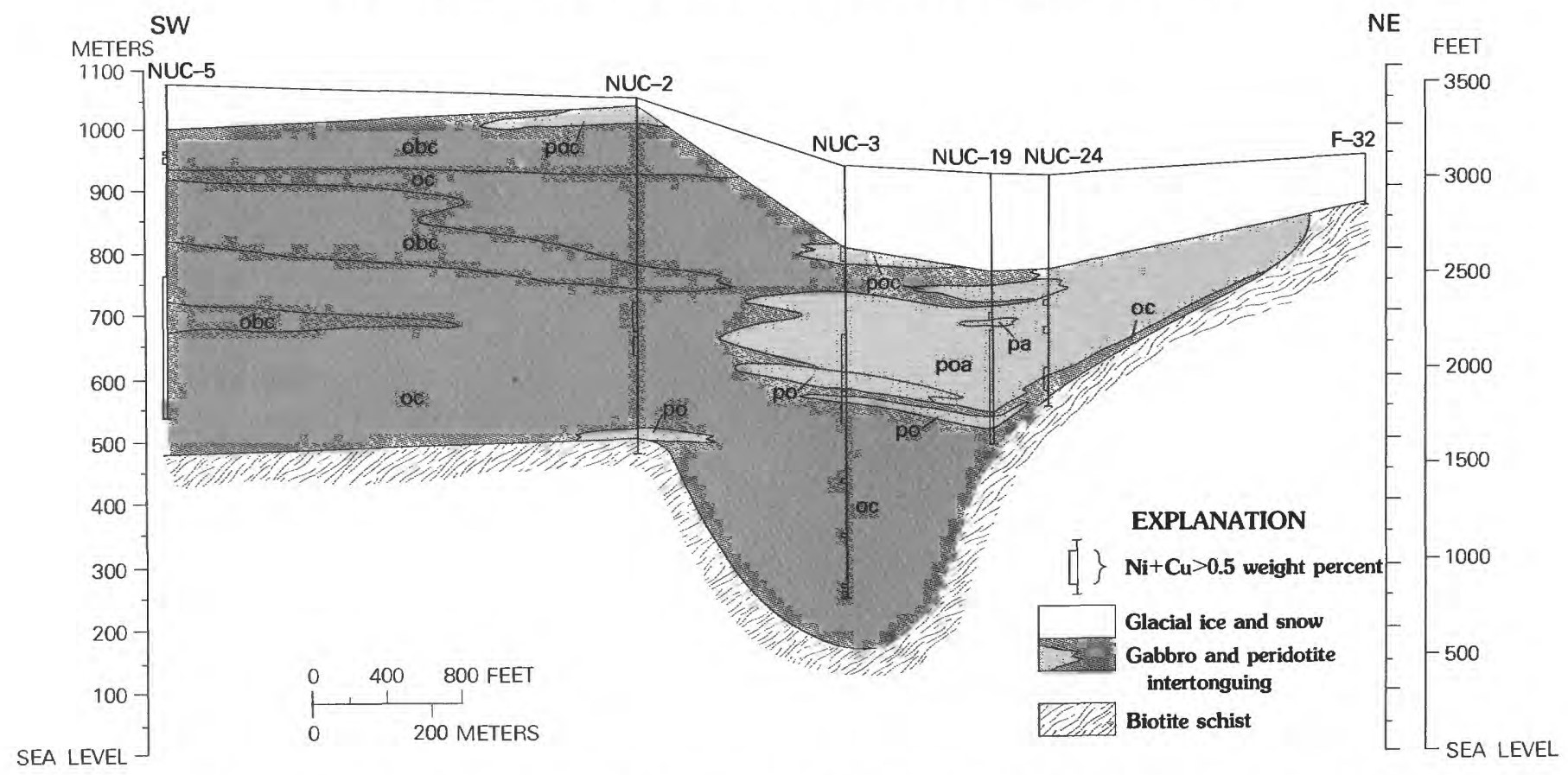

FIGURE 4.-Generalized southwest-northeast cross section through the Brady Glacier cumulates. (See fig. 3 for location.) oc, olivine-chromite cumulate; obc, olivine-bronzite-chromite cumulate; poc, plagioclase-olivine-chromite cumulate; po, plagioclaseolivine cumulate; poa, plagioclase-olivine-augite cumulate; pa, plagioclase-augite cumulate.

clase becomes a cumulus phase. The layers are not laterally continuous over large distances but are lenticular and wedge out in all directions. (See figs. 4 and 5.) Within individual cumulate layers, there is no indication of rhythmic layering, that is, alternation of dark and light layers generally attributed to deposition from convection currents.

The major rock types are olivine cumulate (peridotite and feldspathic peridotite), plagioclase-augite-olivine cumulate (olivine gabbro), olivine-bronzite \pm plagioclase cumulate (harzburgite and feldspathic harzburgite), and olivine-plagioclase cumulate (dominantly olivine gabbro and troctolite, rarely, feldspathic dunite and feldspathic harzburgite). All these cumulates except the plagioclase-augite-olivine cumulate commonly contain a minor amount of cumulus chromite. Thin layers of plagioclase-augite-cumulate (gabbro) and plagioclase cumulate (anorthosite and gabbro) are present but not volumetrically abundant. Graphite is conspicuous in sulfide ore zones (seams to $30 \mathrm{~cm}$ thick) and is commonly observed throughout the gabbroic rocks. The cumulates are cut by numerous dikes that range in composition from hornblende diabase to granodiorite.

At most places, an olivine cumulate forms the lowermost unit. In the eastern part of the Brady Glacier cumulates, olivine cumulate is interlayered upward with olivine-plagioclase cumulates and plagioclase-augite-olivine cumulates. In the western part, the gabbroic rocks wedge out, and the olivine cumulates are interlayered with olivine-bronzite cumulates (fig. 4).

Four drill holes penetrated the contact of the cumulates with the country-rock schist. Two of the cores, NUC-24 and NUC-1 (not in fig. 3), have olivine cumulate in contact with the schist; whereas two others, NUC-2 (too thin to show in figs. 3 and 8) and NUC-10, have an altered noncumulate gabbro in contact with the schist. The contact gabbros are approximately $1 \mathrm{~m}$ thick and consist of plagioclase and amphibole mattes in a diabasic to ophitic texture. The noncumulate gabbro in drill core NUC-2 grades upward into approximately $12 \mathrm{~m}$ of plagioclase-olivine cumulate containing abundant postcumulus clinopyroxene; in drill core NUC-10, the gabbro is in contact upward with olivine cumulate. Whether such gabbros represent a common contact rock, possibly even a chilled marginal gabbro, or are only local lenses is indeterminate. The drill-core data indicate that the contact with the country rock is irregular and has considerable relief. The tendency for the layering to parallel basement contacts (figs. 4, $5,6)$ suggests the draping of sediments over an initial basement topography. However, the extent to which the structure may have been modified by post- 


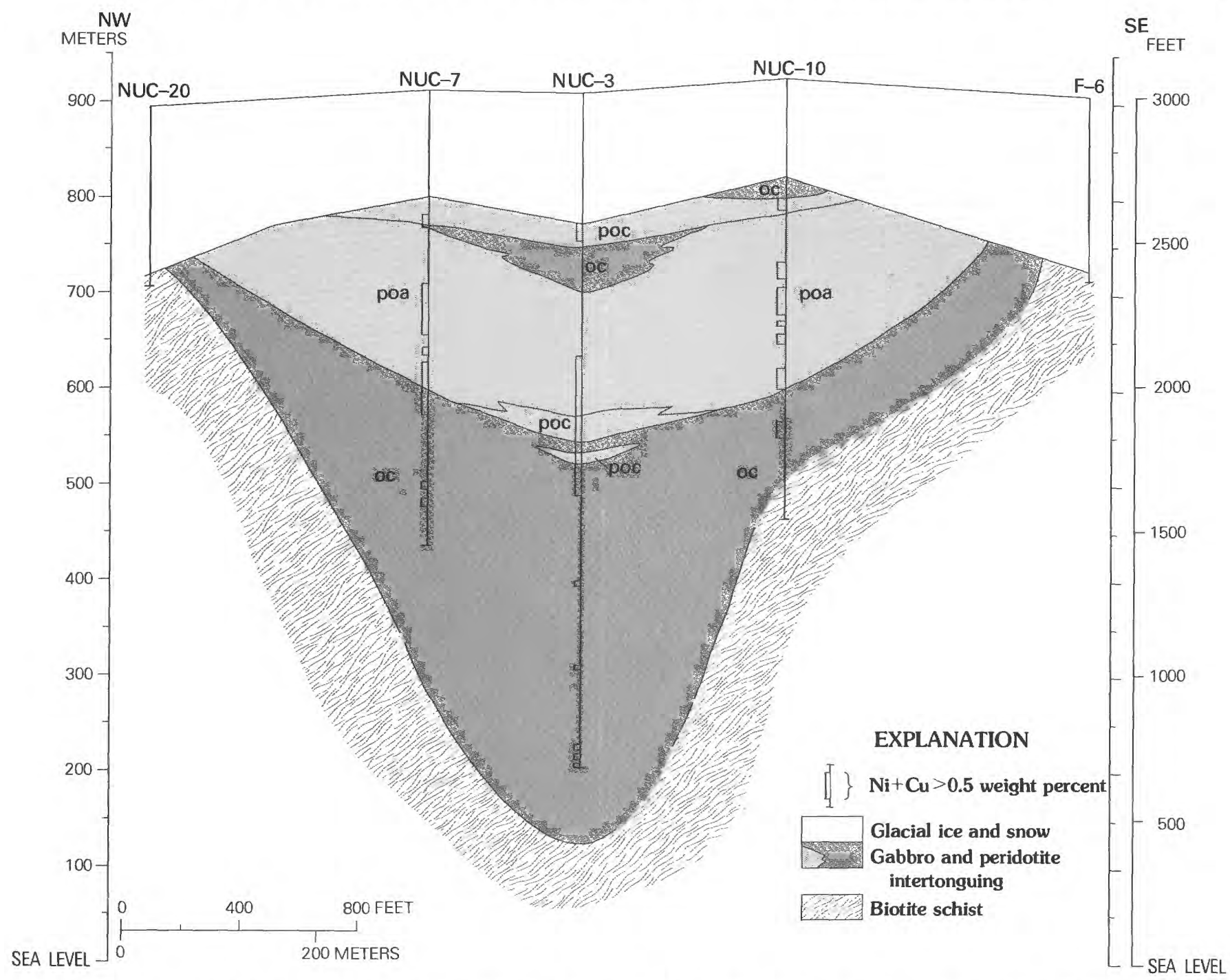

FIGURE 5.-Generalized northwest-southeast cross section through the Brady Glacier cumulates. (see fig. 3 for location.) oc, olivine-chromite cumulate; poc, plagioclase-olivine-chromite cumulate; poa, plagioclase-olivine-augite cumulate.

intrusion faulting is not determinable with the existing corehole control.

In the olivine cumulates, the olivine habit ranges from euhedral in some samples to subhedral and rounded in others. Where olivine is enclosed in augite or brown hornblende oikocrysts, it is commonly embayed, suggesting partial resorption. Cumulus chromite generally makes up less than 1 percent of the cumulus phases, in a few samples of olivine cumulate, 3-5 percent. The chromite is euhedral to subhedral and commonly occurs as small grains enclosed in olivine, but free grains are present. Postcumulus minerals are augite, plagioclase, and brown hornblende that form oikocrysts enclosing the cumulus olivine; bronzite and biotite are rare. Brown hornblende appears to be the latest crystalliz- ing mineral, commonly rimming and partly replacing augite and rimming interstitial sulfide minerals. It is not uncommon for the proportion of postcumulus plagioclase to increase stratigraphically upward such that the olivine cumulate in total mode is an olivine gabbro or troctolite prior to the appearance of plagioclase as a cumulus mineral. Most of the olivine cumulates are peridotite or feldspathic peridotite; some are feldspathic dunite.

Olivine-bronzite cumulates generally have an olivine content greater than orthopyroxene; in some samples, the two cumulus minerals are approximately equal. Small euhedral chromite grains are present in all samples but make up less than 1 percent. Cumulus plagioclase, present in the upper part of drill core NUC-2, makes up less than 5 


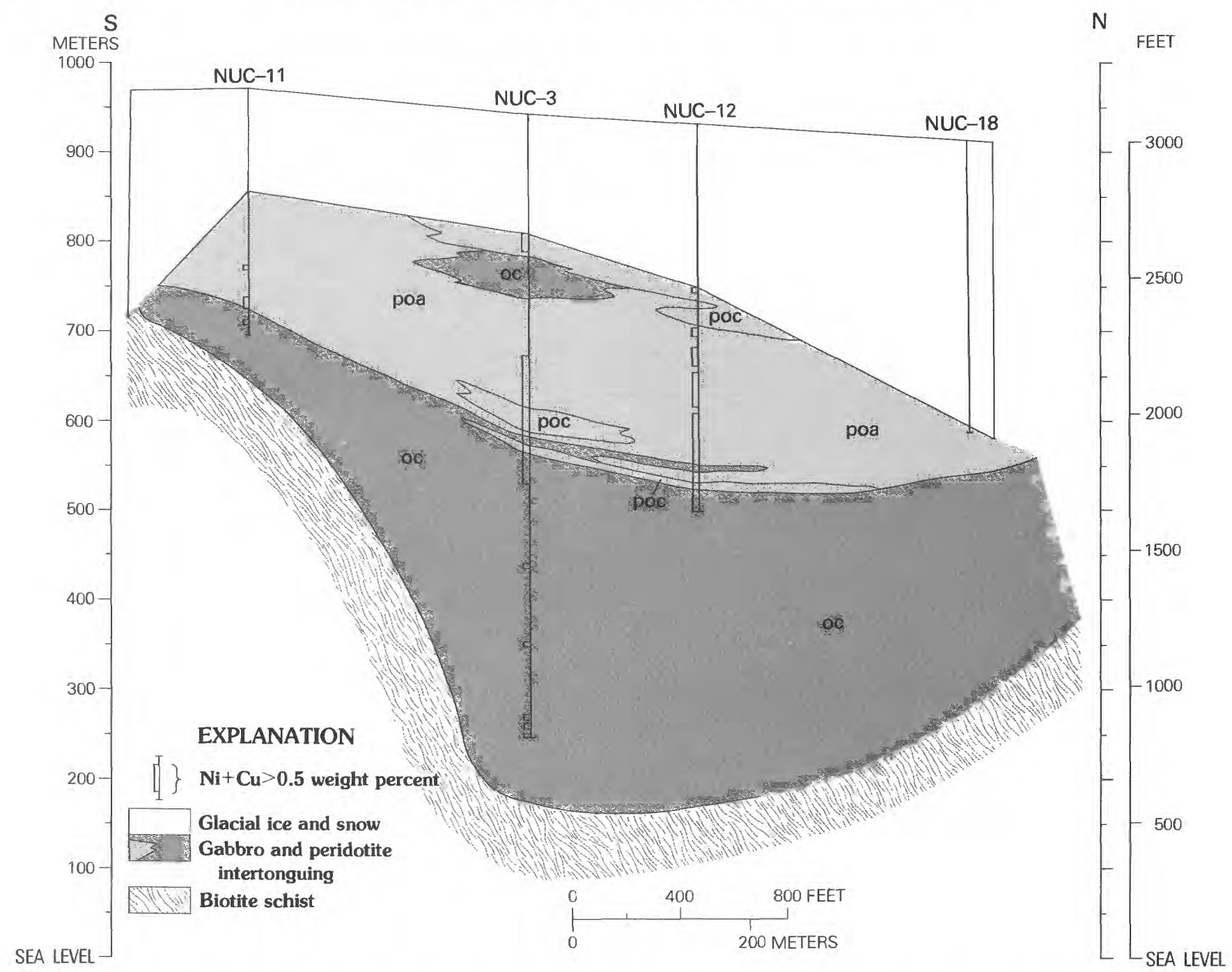

FIGURE 6.-Generalized north-south cross section through the Brady Glacier cumulates. (See fig. 3 for location.) oc, olivinechromite cumulate; poc, plagioclase-olivine-chromite cumulate; poa, plagioclase-olivine-augite cumulate.

percent. Postcumulus minerals consist of plagioclase, augite, and brown hornblende; the proportion of postcumulus minerals is so small that most of the olivine-bronzite cumulates are harzburgite or, less commonly, feldspathic harzburgite.

The plagioclase-augite-olivine cumulates are olivine gabbro with minor amounts of postcumulus bronzite and brown hornblende. The olivine generally occurs as large irregular embayed grains that commonly enclose small plagioclase laths; the olivine + plagioclase grains are believed to have settled as composite grains. Similar composite grains have been described in the Rhum intrusion, Inner Hebrides (Wager and Brown, 1968), where the evidence for settling as a composite cluster is clearly demonstrated. Augite is generally anhedral and angular and partly replaced by the postcumulus hornblende.
Most of the plagioclase-olivine cumulates have a trace of cumulus chromite. Postcumulus minerals are generally augite and brown hornblende; some samples contain postcumulus orthopyroxene. Most samples have plagioclase exceeding olivine in amount and are olivine gabbro or troctolite, depending on the amount of postcumulus augite. Where olivine exceeds plagioclase, the samples are most commonly feldspathic dunite or feldspathic harzburgite. Olivine may be subhedral but more commonly is irregular and embayed. Where olivine is enclosed in augite, it is generally rounded, suggesting a reaction relation.

Secondary alteration of the cumulates is common. The peridotite commonly is altered to a mixture of chlorite, amphibole, and serpentine; olivine and pyroxene of the gabbroic rocks are altered to mattes 


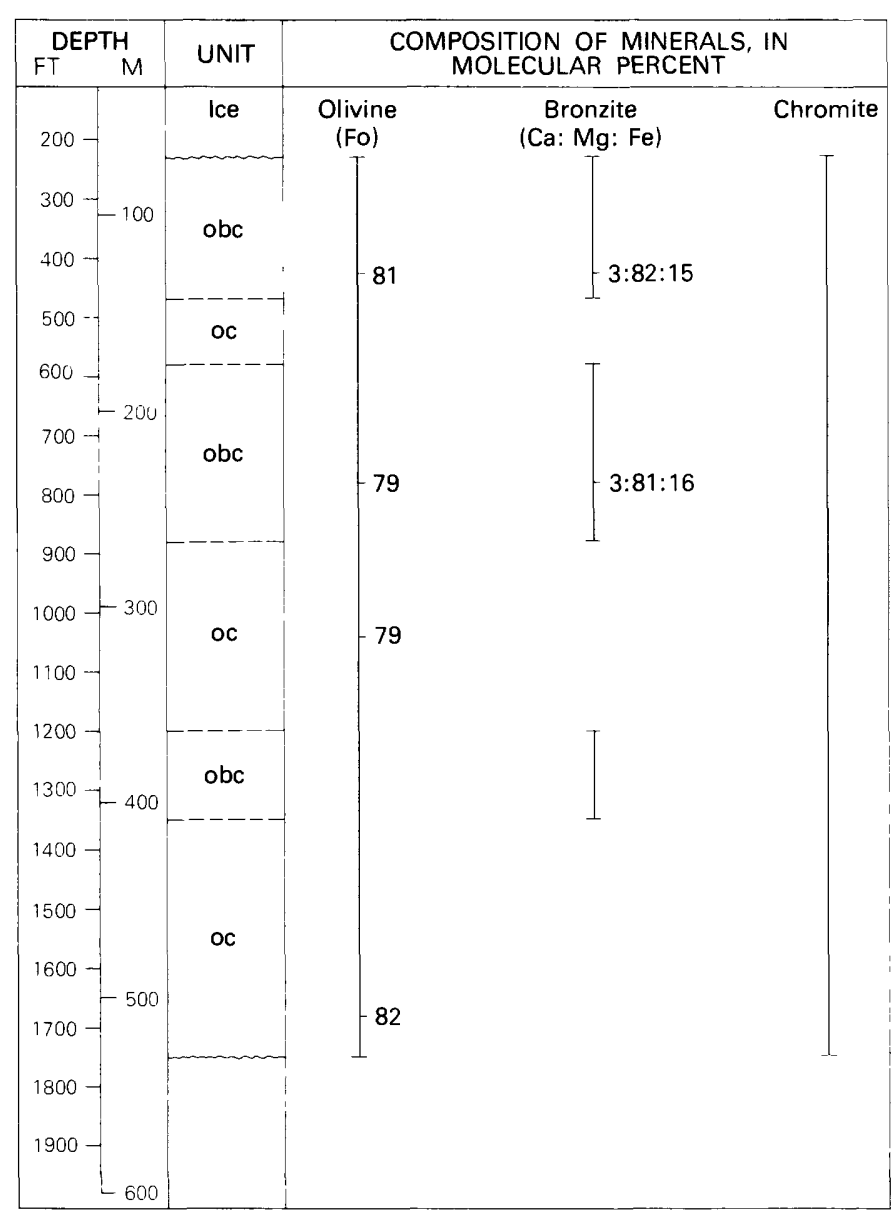

FIgURE 7.-Section for core NUC-5 showing major cumulate units, stratigraphic distribution of cumulus minerals, and composition of analyzed minerals. oc, olivine-chromite cumulate; obc, olivine-bronzite-chromite cumulate.

of amphibole, but the plagioclase generally remains unaltered. Coronas on olivine in contact with plagioclase are common.

\section{OCCURRENCE AND MINERALOGY OF SULFIDE MINERALS}

The Brady Glacier nickel-copper deposit is composed predominantly of disseminated interstitial sulfide minerals in the ultramafic and gabbroic cumulates; massive sulfide pods as much as $3 \mathrm{~m}$ thick have been penetrated by drilling. The sulfide mineralogy throughout the basàl cumulates consists predominantly of hexagonal and monoclinic pyrrhotite, pentlandite, and chalcopyrite (Czamanske and others, 1978). In some samples, the amount of disseminated sulfide minerals is as high as 10 percent.

Although the occurrence of disseminated sulfide minerals shows no relation to stratigraphic position or rock type, the massive sulfide pods tend to be concentrated along the boundaries between mafic and ultramafic layers. The distribution of copper + nickel greater than 0.5 percent is shown in figures 4 , 5 , and 6 . Indicated ore reserves are greater than 100 million tons of approximately 0.5 percent nickel and 0.30 percent copper (Czamanske and others, 1978). The textural characteristics indicate that the sulfide minerals formed from an immiscible sulfide melt.

\section{ROCK CHEMISTRY}

Bulk chemical compositions were obtained by $\mathrm{X}$-ray fluorescence methods for 19 rock samples from four drill cores; the analyses are given in table 1 in order of increasing stratigraphic height for each core. With one exception, all samples are cumulates; sample NUC-10-1340 is a noncumulate gabbro in contact with the metamorphic rocks. The rock compositions are dependent on bulk modal mineralogy and do not reflect the distinction between cumulus minerals and the postcumulus material that crystallized from intercumulus liquid. Any interpretation of variation in chemistry must consider variation in kind and amount of both the cumulus phases and the postcumulus material.

The variation in chemistry of the ultramafic and gabbroic rocks is best illustrated with $\mathrm{MgO}$ variation diagrams (fig. 11). For plotting, the analyses were normalized to 100 percent dry weight. " $\mathrm{FeO}$ " is total iron calculated after normalization of the analyses. The range of composition of the cumulus phases olivine, bronzite, augite, and plagioclase is plotted on the variation diagrams to aid in interpreting the various mineral controls on the chemical composition of the rocks.

In relation to $\mathrm{MgO}$ content, the compositions fall into two groups. Those rocks with $\mathrm{MgO}$ greater than 25 percent are, with one exception, olivine cumulates and olivine-bronzite cumulates; the exception is an olivine-plagioclase cumulate whose modal plagioclase is significantly less than that of the other olivine gabbros. Postcumulus minerals in the ultramafic rocks are dominantly augite and plagioclase. In these rocks, the range in $\mathrm{MgO}$ content is largely produced by the variation in amount of plagioclase. The second group has $\mathrm{MgO}$ contents less than 20 percent. These rocks are plagioclase-olivineaugite cumulates, plagioclase-augite cumulates, plagioclase-olivine cumulates, and the noncumulate gabbro. Postcumulus mineralogy is represented by augite in those rocks where it is not a cumulus phase and commonly by minor brown hornblende.

In the ultramafic rocks (those with $\mathrm{MgO}$ greater 
TABLE 1.-Chemical composition of basal (Brady Glacier) cumulates of the La Perouse layered gabbro

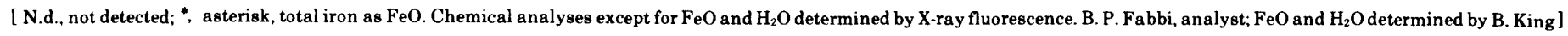

\begin{tabular}{|c|c|c|c|c|c|c|c|c|c|c|c|c|c|c|c|c|c|c|c|}
\hline \multirow{2}{*}{$\begin{array}{r}\text { Drill core } . . . . . \\
\text { Sample No. and } \\
\text { depth, in feet }\end{array}$} & \multicolumn{2}{|c|}{ NUC-5 } & \multicolumn{4}{|c|}{ NUC-2 } & \multicolumn{4}{|c|}{ NUC -7} & \multicolumn{9}{|c|}{ NUC -10} \\
\hline & 1678 & 426 & 1770 & 1122 & 303 & $34 \mathrm{~A}$ & 1145 & 864 & 529 & 412 & 1340 & 1271 & 879 & 765 & 505 & 484 & 458 & 424 & 381 \\
\hline $\mathrm{SiO}_{2}$ & 39.45 & 42.27 & 46.38 & 38.81 & 40.98 & 42.11 & 40.58 & 46.57 & 51.16 & 45.88 & 47.96 & 43.82 & 44.80 & 40.98 & 49.73 & 40.66 & 48.53 & 42.79 & 40.53 \\
\hline $\mathrm{Al}_{2} \mathrm{O}_{3} \ldots$ & 3.91 & 4.18 & 12.47 & 1.82 & 4.77 & 8.28 & 2.62 & 15.57 & 14.63 & 17.24 & 18.27 & 8.68 & 12.18 & 16.89 & 21.08 & 8.39 & 22.56 & 22.50 & 4.24 \\
\hline $\mathrm{Fe}_{2} \mathrm{O}_{3} \ldots \ldots \ldots$ & $\begin{array}{r}0.91 \\
-\quad .92\end{array}$ & 1.23 & $\begin{array}{r}12.41 \\
.73\end{array}$ & 2.60 & .43 & $\begin{array}{l}0.00 \\
1.07\end{array}$ & $\begin{array}{r}.02 \\
.52\end{array}$ & .65 & $\begin{array}{r}14.00 \\
.30\end{array}$ & .53 & $\begin{array}{r}10.21 \\
.81\end{array}$ & $\begin{array}{l}0.00 \\
1.15\end{array}$ & 1.40 & N.d. & $\begin{array}{r}.35 \\
.35\end{array}$ & $\begin{array}{l}.05 \\
1.22\end{array}$ & .32 & 2.28 & 1.39 \\
\hline $\mathrm{FeO}$ & 13.04 & 12.08 & 8.38 & 11.02 & 15.55 & 12.89 & 11.67 & 6.76 & 4.17 & 6.64 & 5.69 & 9.14 & 10.25 & $12.16^{*}$ & 3.14 & 13.50 & 2.65 & 6.12 & 12.53 \\
\hline MgO................... & 35.53 & 32.94 & 18.14 & 39.66 & 32.17 & 27.79 & 40.51 & 13.22 & 10.67 & 15.21 & 10.26 & 26.98 & 18.55 & 15.34 & 7.14 & 26.91 & 7.24 & 8.39 & 34.50 \\
\hline …........ & $\begin{array}{r}2.61 \\
.\end{array}$ & 3.10 & $\begin{array}{r}10.14 \\
9.37\end{array}$ & 1.29 & 2.89 & 5.00 & 1.92 & 13.12 & 16.98 & 10.69 & $\begin{array}{l}10.20 \\
11.52\end{array}$ & $\begin{array}{r}20.90 \\
6.20\end{array}$ & 8.74 & 8.14 & 15.52 & 4.84 & 15.81 & 12.25 & 3.63 \\
\hline $\mathrm{Na}_{2} \mathrm{O}$ & $\begin{array}{r}. \quad 44 \\
\end{array}$ & .52 & 1.81 & .25 & .52 & .74 & .36 & 1.42 & 1.55 & 1.84 & 2.95 & 1.15 & 1.21 & 1.66 & 2.17 & .86 & 1.72 & 1.68 & .59 \\
\hline $\mathrm{K}_{2} \mathrm{O} \ldots \ldots \ldots \ldots$ & .02 & .03 & .14 & .01 & .07 & .08 & .01 & .03 & .03 & $\begin{array}{r}.07 \\
.03\end{array}$ & $\begin{array}{r}.50 \\
.20\end{array}$ & .04 & .03 & .07 & .03 & .02 & .03 & .04 & .03 \\
\hline $\mathrm{H}_{2} \mathrm{O}^{\prime} \ldots \ldots \ldots \ldots \ldots$ & 2.52 & 2.01 & .84 & 3.50 & 1.13 & 1.01 & .17 & .57 & .35 & .48 & 1.20 & 1.46 & .00 & N.d. & .82 & 1.03 & .81 & .72 & .75 \\
\hline $\mathrm{H}_{2} \mathrm{O}$ & $\begin{array}{r}.02 \\
-\quad .02\end{array}$ & .04 & .02 & .04 & .01 & .02 & .04 & .04 & .01 & .02 & .01 & .08 & .05 & N.d. & .01 & .01 & .01 & .00 & .11 \\
\hline $\mathrm{TiO}_{2} \ldots \ldots \ldots \ldots$ & .08 & .16 & .57 & .13 & .13 & .20 & .11 & .30 & .38 & .23 & .55 & .32 & .27 & .27 & .26 & .14 & .21 & .17 & .15 \\
\hline $\mathrm{P}_{2} \mathrm{O}_{5} \ldots \ldots$ & .01 & .01 & .03 & .02 & .02 & .02 & .02 & .00 & .00 & .00 & .06 & .04 & .02 & .01 & .00 & .02 & .00 & .00 & .02 \\
\hline $\mathrm{MnO}$ & .18 & .20 & .15 & .20 & .23 & .20 & .16 & .11 & .10 & .12 & .10 & .14 & .14 & .13 & .08 & .18 & .06 & .07 & .17 \\
\hline 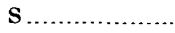 & .63 & .14 & .11 & .36 & .30 & .27 & .48 & .73 & .07 & .08 & .16 & $\begin{array}{l}.14 \\
.11\end{array}$ & 1.09 & 1.93 & .05 & .82 & .06 & 2.50 & 1.11 \\
\hline Subtotal... & 99.36 & 98.91 & 99.14 & 99.71 & 99.20 & 99.68 & 99.17 & 99.09 & 100.40 & 98.99 & 100.13 & 99.31 & 99.42 & 98.46 & 100.38 & 98.60 & 100.01 & 99.51 & 99.75 \\
\hline Less 0 . & .31 & .07 & .05 & .18 & .18 & .13 & .24 & .36 & .03 & .04 & .08 & .05 & .54 & .96 & .02 & .41 & .03 & 1.25 & .55 \\
\hline Total & 99.05 & 98.84 & 99.09 & 99.53 & 99.05 & 99.55 & 98.93 & 98.73 & 100.37 & 98.95 & 100.05 & 99.26 & 98.88 & 97.50 & 100.36 & 98.19 & 99.98 & 98.26 & 99.20 \\
\hline
\end{tabular}

ROCK TYPE

\begin{tabular}{|c|c|c|c|}
\hline NUC-5-1678 & Olivine-chromite cumulate (wehrlite) & NUC $-10-1340$ & Noncumulate, altered gabbro \\
\hline 426 & $\begin{array}{l}\text { Olivine-bronzite-chromite cumulate (plagioclase } \\
\text { bearing harzburgite) }\end{array}$ & $\begin{array}{r}1271 \\
879\end{array}$ & $\begin{array}{l}\text { Olivine-chromite cumulate (plagioclase bearing periodotite) } \\
\text { Plagioclase-augite-olivine cumulate (olivine gabbro) }\end{array}$ \\
\hline NUC-2 -1770 & Plagioclase-olivine cumulate (olivine gabbro) & 765 & Plagioclase-olvine cumulate (olivine gabbro) \\
\hline$\lfloor 122$ & Olivine-chromite cumulate (dunite) & 505 & Plagioclase-augite-olivine cumulate (gabbro) \\
\hline 303 & $\begin{array}{l}\text { Olivine-bronzite-plagioclase-chromite cumulate } \\
\text { (plagioclase bearing harzburgite) }\end{array}$ & 484 & $\begin{array}{l}\text { Olivine-plagioclase cumulate (plagioclase bearing dunite- } \\
\text { harzburgite) }\end{array}$ \\
\hline $34 \mathrm{~A}$ & Plagioclase-olivine-chromite cumulate (olivine gabbro) & 458 & Plagioclase-augite cumulate (gabbro) \\
\hline NUC- $7-1145$ & Olivine-chromite cumulate (plagioclase bearing dunite) & 424 & Plagioclase-olivine cumulate (troctolite) \\
\hline 864 & Plagioclase-augite-olivine cumulate (olivine gabbro) & 381 & Olivine-chromite cumulate (plagioclase bearing wehrlite) \\
\hline 529 & Plagioclase-augite-olivine cumulate (gabbro) & & \\
\hline 412 & Plagioclase-olivine-chromite cumulate (olivine gabbro) & & \\
\hline
\end{tabular}

than 25 percent), the compositions are predominantly controlled by the composition of the cumulus olivine. Variation in amounts of major oxides reflects the relative amounts of cumulus olivine and post-cumulus minerals, particularly plagioclase. In the gabbroic rocks, postcumulus minerals are not so abundant and the variation of $\mathrm{Al}_{2} \mathrm{O}_{3}, \mathrm{SiO}_{2}$, and $\mathrm{Na}_{2} \mathrm{O}$ essentially reflects the proportions of cumulus olivine and plagioclase. The amounts of $\mathrm{CaO}$, "FeO," and $\mathrm{MnO}$ are influenced by augite as well as by olivine and plagioclase. $\mathrm{TiO}_{2}$ values show a broad scatter on the variation diagram and might reflect small amounts of ilmenite not identified in thin section. The low $\mathrm{Fe}_{2} \mathrm{O}_{3}$ content of the rocks indicates a reduced state.

In the MgO-oxide diagrams, the data plot on a smooth trend, reflecting the fact that the ultramafic and gabbroic rocks are related by differentiation of the same magma or similar magmas. Further, even though the gabbroic rocks are cumulates with a small amount of postcumulus material, and therefore not truly representative of successive liquids, the trends of the MgO-oxide variations for the gabbroic rocks extrapolate to the olivine composition, indicating that the primary mechanism for derivation of the gabbro was olivine fractionation.

\section{CHEMISTRY OF CUMULUS MINERALS}

Cumulus minerals in 30 specimens from four drill cores were analyzed with an ARL EMX-SM electron microprobe, using natural and synthetic minerals and oxides of known composition as standards. Corrections were made for background, nass absorption, secondary fluorescence, and atomic number. Structural formulas for all minerals were calculated by the hydrogen-equivalent method of Jackson and others (1967). The analyses are given in tables 2 through 6 in order of increasing stratigraphic height for each drill core. The compositions are plotted relative to the cumulate stratigraphy of each core in figures 7 through 10 .

\section{OLIVINE}

Olivine, a cumulus phase in all the Brady Glacier cumulates except in rare plagioclase-augite cumulates, is the best mineralogical indicator of the fractional crystallization of the magma that produced the Brady Glacier cumulates. For the olivine analyses given in table 2 , each analysis is the average of a minimum of 5 points per grain. Homogeneity of individual grains indicates that 


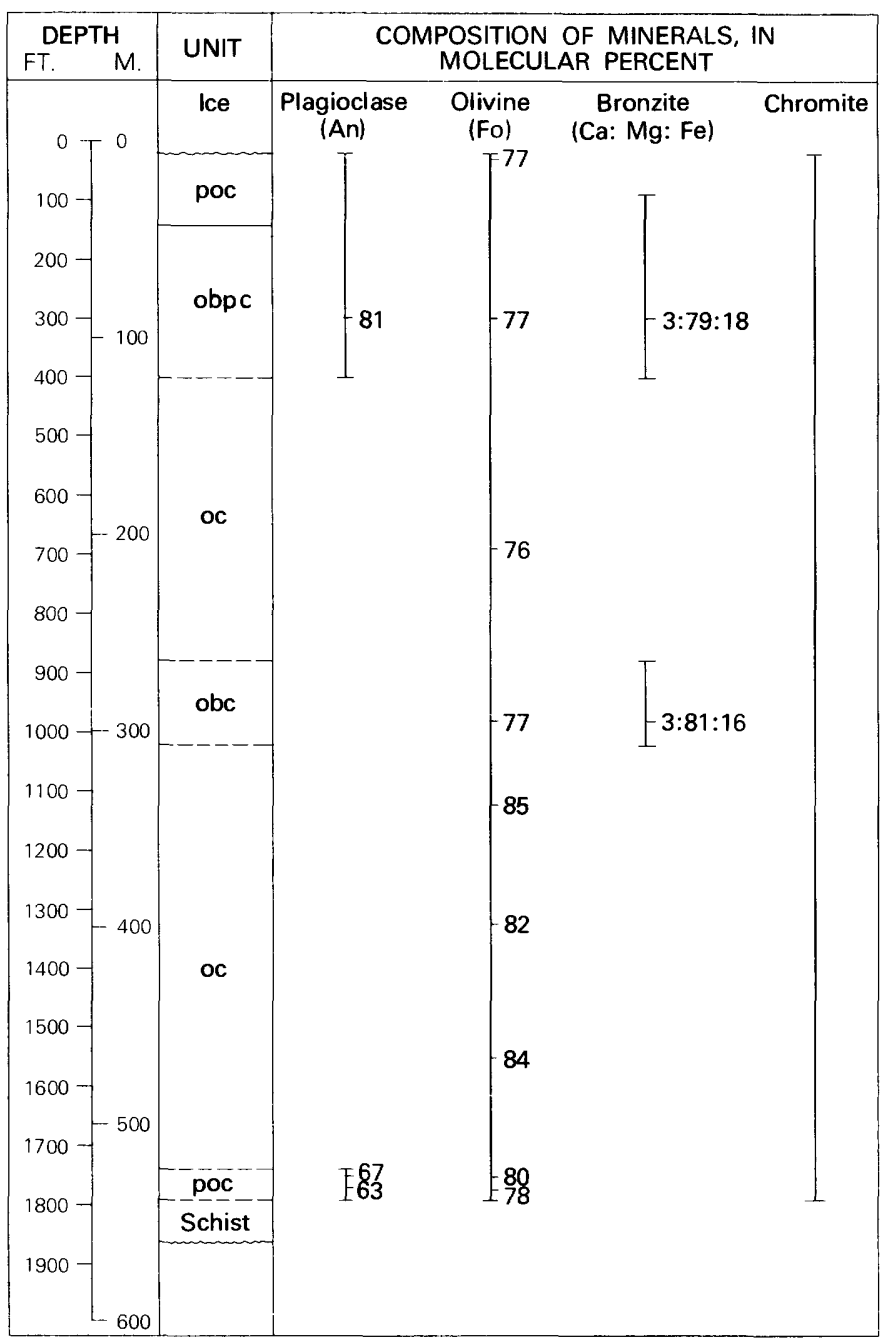

FIGURE 8.-Section for core NUC-2 showing major cumulate units, stratigraphic distribution of cumulus minerals, and composition of analyzed minerals. oc, olivine-chromite cumulate; obc, olivine-bronzite-chromite cumulate; poc, plagioclaseolivine-chromite cumulate; obpc, olivine-bronzite-plagioclase-chromite cumulate.

there was no postcumulus lower temperature growth of olivine; either the olivine grains are entirely cumulus or postcumulus growth was by an adcumulus process. There is no significant grainto-grain compositional variation.

The range in composition for all samples is Fo $\mathrm{F}_{86.1}$ to $\mathrm{Fo}_{71.2}$. Olivine in olivine cumulates ranges in composition from $\mathrm{Fo}_{86.1}$ to $\mathrm{Fo}_{73.3}$; most samples have olivine with a forsterite content greater than 80 . Olivine-bronzite cumulates contain olivine of composition $\mathrm{Fo}_{81.1}$ to $\mathrm{Fo}_{\text {77.2. }}$. Although there is some compositional overlap, samples that contain cumulus plagioclase generally have olivine that is more iron-rich $\left(\mathrm{Fo}_{79.7}\right.$ to $\left.\mathrm{Fo}_{71.2}\right)$ than do those samples without cumulus plagioclase.

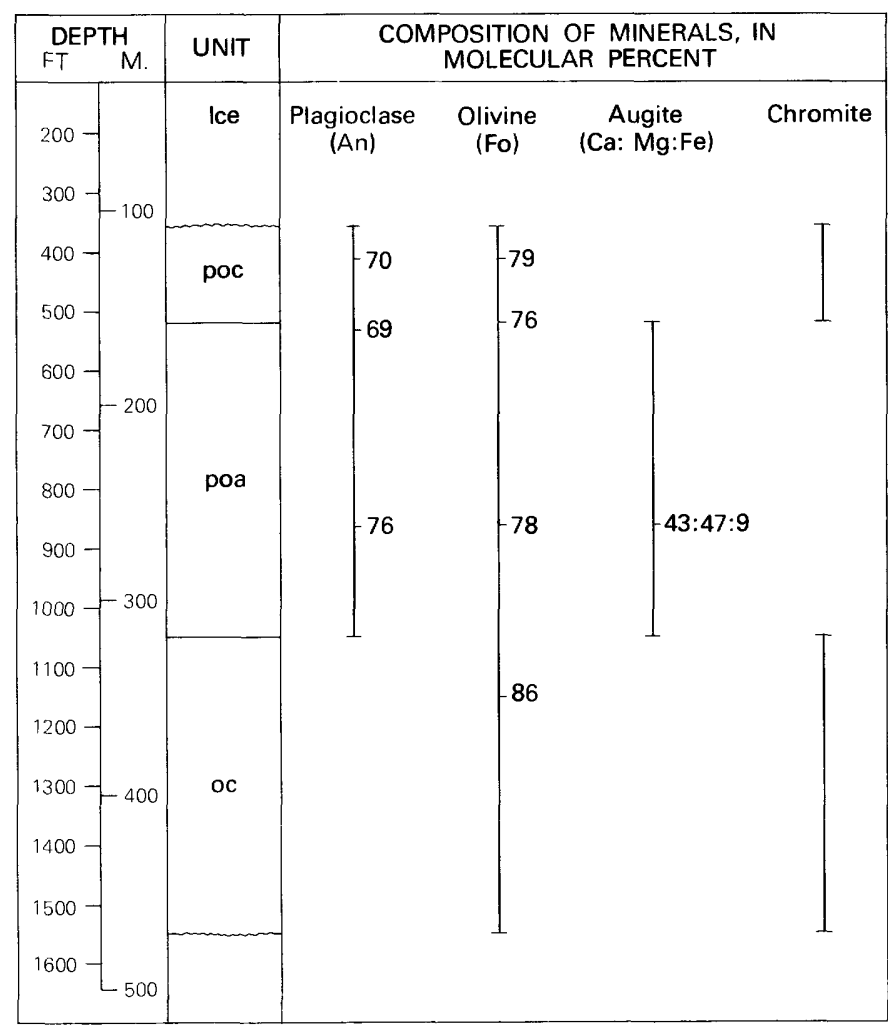

FIgURE 9.-Section for core NUC-7 showing major cumulate units, stratigraphic distribution of cumulus minerals, and composition of analyzed minerals. oc, olivine-chromite cumulate; poa, plagioclase-olivine-augite cumulate; poc, plagioclaseolivine-chromite cumulate.

Jackson (1970) and Page and others (1972) documented evidence that in the Stillwater Complex, Montana, olivine within a single cumulate layer can vary widely in composition. A similar variation in olivine composition was shown by G. K. Czamanske and L. C. Calk (written commun., 1978) in the lower olivine-cumulate layer of core NUC-5, where the olivine composition varies from approximately $\mathrm{Fo}_{83}$ to $\mathrm{Fo}_{78}$ with no relation to stratigraphic height (fig. 12). Irvine (1965, 1967) and Jackson (1969) demonstrated that the composition of olivine with cumulus chromite varies sympathetically with both chromite composition and abundance. In the Brady Glacier cumulates, chromite occurs with many of the olivine-bearing cumulates but is never an abundant phase (generally less than 1 percent). Because its composition varies widely within a single sample, a relation between olivine composition and chromite composition or abundance has not been established.

Cumulate layers are repeated stratigraphically upward. The data, though not conclusive, suggest that olivine in higher olivine cumulate layers, with few exceptions (for example, NUC-10), is less 


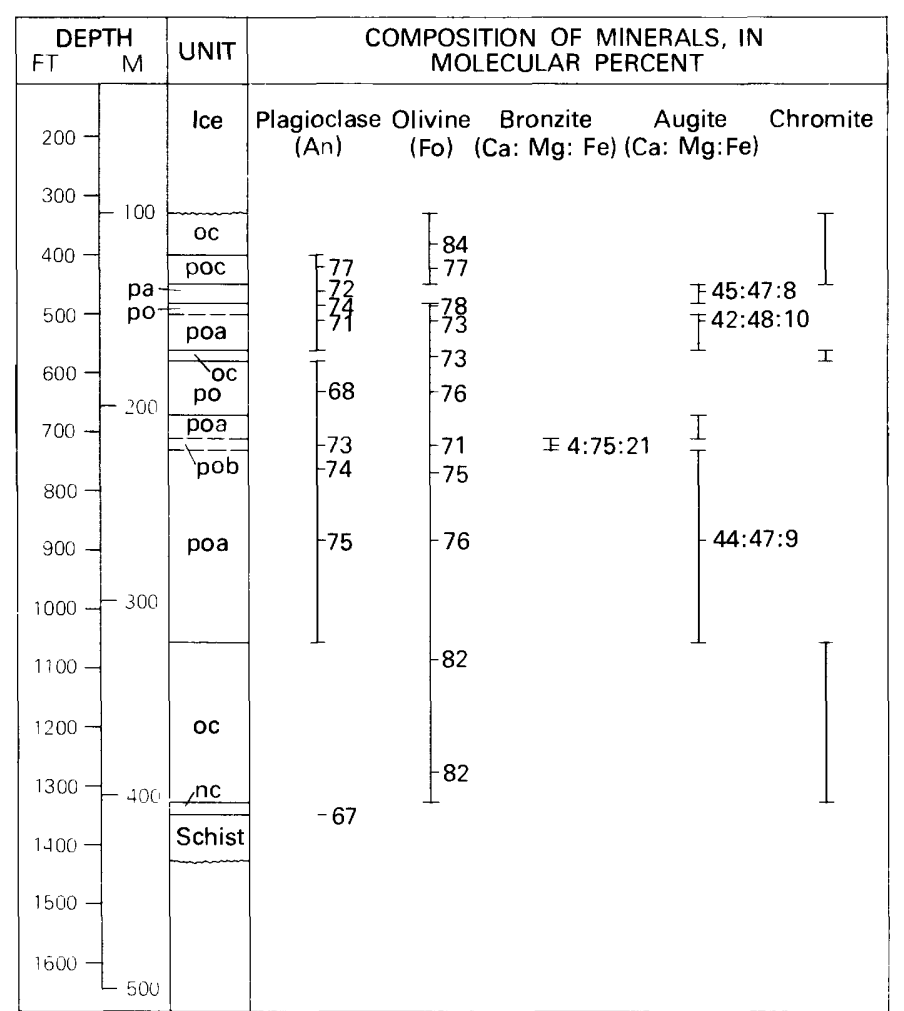

FIGURE 10.-Section for core NUC-10 showing major cumulate units, stratigraphic distribution of cumulus minerals, and composition of analyzed minerals. oc, olivine-chromite cumulate; poa, plagioclase-olivine-augite cumulate; pob, plagioclase-olivine-bronzite cumulate; po, plagioclase-olivine cumulate; $p o c$, plagioclase-olivine-chromite cumulate; pa, plagioclase-augite cumulate; nc, noncumulate gabbro.

forsteritic than olivine in lower olivine cumulates. Compositional variation of olivine within a single unit and the absence of specific recognizable horizons within the units make it difficult to compare olivine compositions laterally between cores.

$\mathrm{MnO}$ ranges from 0.18 to 0.36 percent and in general increases with $\mathrm{FeO}$ content. $\mathrm{NiO}$ in olivine ranges from "not detectable" to 0.28 percent and shows no relation to forsterite content or rock type.

\section{PYROXENE}

Chemical composition and structural formulas of bronzite and augite are given in tables 3 and 4 . Both the bronzite and augite have narrow, closely spaced exsolution lamellae that generally can not be adequately resolved with the electron microprobe; bulk analyses of the pyroxenes were obtained by traversing the grains with a broad electron beam $1 \approx 25 \mu \mathrm{m}$ diameter). Differences in composition from grain to grain obtained in this manner are not significant. The presence of exsolution lamellae and the method of analysis, however, do preclude determination of any chemical inhomogeneities or zoning that might be related to either cumulus or postcumulus growth.

Cumulus bronzite occurs primarily in the western part of the Brady Glacier cumulates (cores NUC-5 and NUC-2, figs. 7 and 8), mainly with cumulus olivine, minor amounts of cumulus chromite, and, rarely, with cumulus plagioclase. Nowhere in the Brady Glacier cumulates does cumulus bronzite occur with cumulus augite. The analyzed bronzite has a very limited range of composition; the sample most enriched in iron occurs in a thin layer $(<5 \mathrm{~m})$ of plagioclase-olivine-bronzite cumulate (core NUC-10, fig. 10).

The cumulus augite occurs in gabbro with cumulus plagioclase and generally cumulus olivine; it does not occur as a cumulus phase in peridotite or harzburgite. All analyzed augite is magnesium rich and shows no significant difference in composition regardless of stratigraphic height or lateral position. Postcumulus augite from two samples of olivine gabbro at the base of core NUC-2 (fig. 8) are of the same composition as the analyzed cumulus augites (table 5).

The major- and minor-element contents of the bronzite and augite are similar to values reported for pyroxenes in other cumulates from the lower part of stratiform complexes (Hess, 1960; Atkins, 1969; Cameron, 1978).

\section{PLAGIOCLASE}

In those samples where plagioclase is a cumulus phase, most grains show compositional zoning. Some of this zoning may be related to cumulus growth; much of it may be related to postcumulus growth about the original primocryst. Maal $\phi e$ (1976) documented the complex compositional zoning of plagioclase in the Skaergaard intrusion and illustrated criteria used to distinguish primocryst from postcumulus overgrowth. In the Brady Glacier plagioclase, distinction between primocyrst and postcumulus overgrowth is rarely certain. Plagioclase analyses given in table 5 are representative of average compositions of single plagioclase grains that include primocryst and any postcumulus overgrowth. Differences in composition from grain to grain in the same sample are as great as 7 percent of the amount present and probably largely reflect different ratios of primocryst to postcumulus material and depth of sectioning through the compositionally zoned grains. The analyzed plagioclase shows a range in average composition of $\mathrm{An}_{81}$ to $\mathrm{An}_{63}$ with the most anorthite-rich plagioclase in the olivine-bronzite-plagio- 


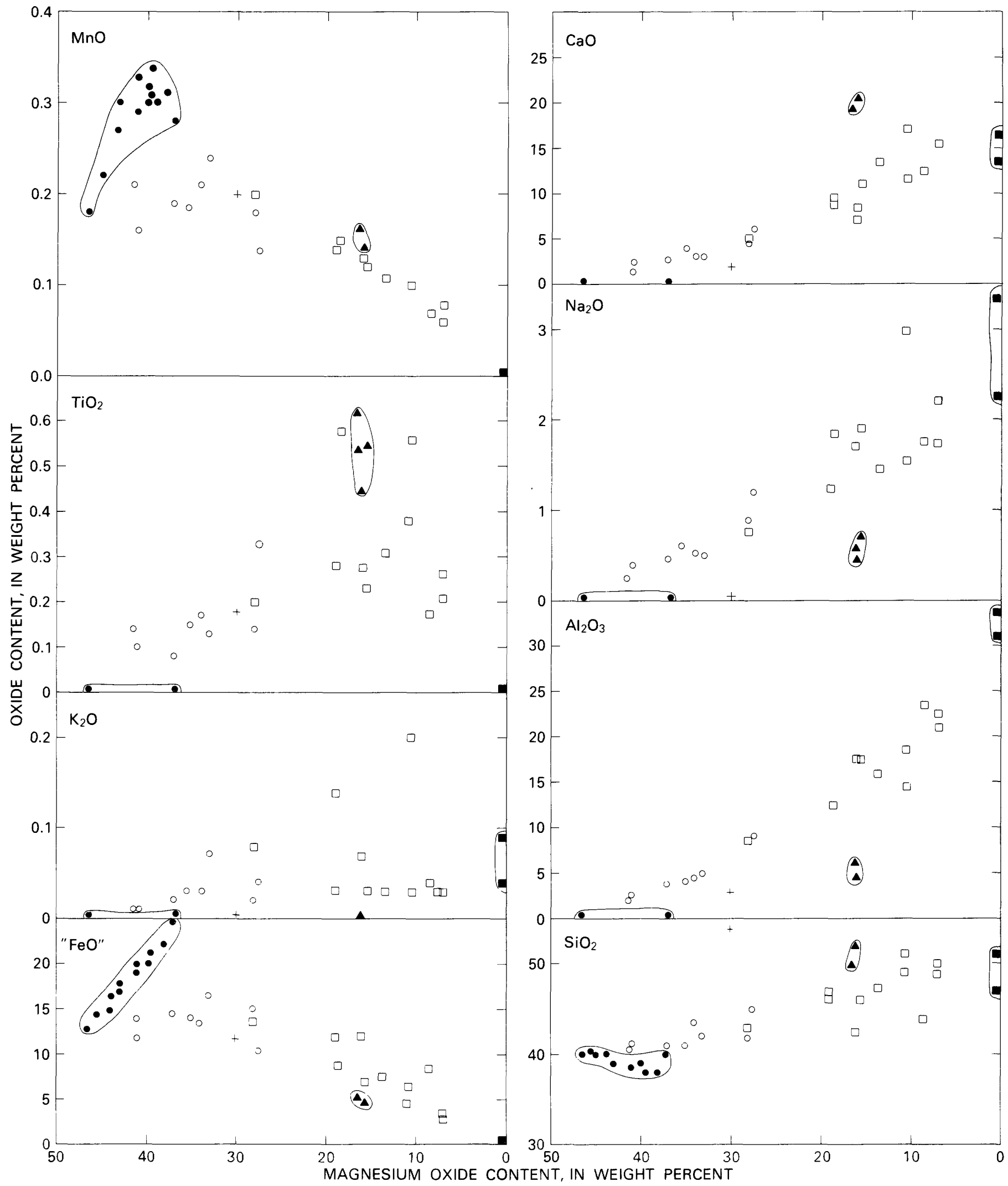

FIGURE 11.-MgO variation diagrams of Brady Glacier cumulate rock samples and cumulus minerals. Open circle, peridotite; open square, gabbro; solid circle, olivine; solid square, plagioclase; solid triangle, augite; cross, bronzite. Fields of mineral composition outlined. 
TABLE 2.-Chemical composition and structural formulas of olivine in the basal (Brady

[Nd., not detected.*, asterisk, total iron as

\begin{tabular}{|c|c|c|c|c|c|c|c|c|c|c|c|c|c|c|c|c|c|}
\hline \multirow{2}{*}{$\begin{array}{l}\text { Drill core } \\
\text { Sample No. and depth, in feet }\end{array}$} & \multicolumn{4}{|c|}{ NUC-5 } & \multicolumn{9}{|c|}{ NUC-2 } & \multicolumn{4}{|c|}{ NUC-7 } \\
\hline & 1678 & 1038 & 784 & 426 & 1770 & 1746 & 1550 & 1318 & 1122 & 980 & 689 & 303 & $34 \mathrm{~A}$ & 1145 & 864 & 529 & 412 \\
\hline $\mathrm{SiO}_{2}$ & 39.3 & 38.8 & 38.9 & 39.6 & 39.0 & 39.3 & 40.0 & 38.5 & 40.4 & 38.8 & 38.6 & 38,2 & 39.1 & 40.3 & 38.6 & 38.0 & 38.4 \\
\hline $\mathrm{FeO}^{*} .$. & 17.1 & 19.4 & 19.0 & 17.7 & 20.2 & 18.8 & 14.7 & 17.0 & 14.4 & 20.7 & 21.9 & 20.7 & 20.8 & 13.2 & 19.7 & 22.0 & 19.3 \\
\hline MgO & 42.9 & 41.3 & 41.5 & 43.2 & 40.3 & 41.9 & 45.1 & 43.0 & 45.4 & 39.9 & 39.5 & 39.6 & 39.7 & 46.5 & 41.0 & 39.2 & 40.8 \\
\hline MnO & .29 & .30 & .24 & .27 & .32 & .26 & .24 & .25 & .22 & .27 & .32 & .30 & .31 & .18 & .29 & .30 & .33 \\
\hline NiO & .10 & .12 & .28 & .06 & .13 & .15 & .13 & .10 & .09 & .07 & .06 & .04 & .06 & .12 & .09 & N.d. & .07 \\
\hline Total & 99.69 & 99.92 & 99.92 & 100.83 & 9.95 & 0.41 & 100.17 & 98.85 & 100.51 & 99.74 & 100.38 & 98.84 & 99.97 & 100.30 & 99.68 & 99.50 & 98.90 \\
\hline
\end{tabular}

Cations per 4 oxygens

\begin{tabular}{|c|c|c|c|c|c|c|c|c|c|c|c|c|c|c|c|c|c|}
\hline $\mathbf{S i}$ & 1.000 & 0.996 & 0.997 & 0.999 & 1.004 & 1.000 & 1.001 & 0.989 & 1.005 & 1.003 & 0.998 & 0.999 & 1.008 & 1.000 & 0.996 & 0.993 & 0.996 \\
\hline $\mathrm{Fe}^{* t}$ & .364 & .417 & .407 & .373 & .434 & .400 & .308 & 366 & .299 & .449 & .474 & .452 & .449 & .273 & .425 & .481 & .419 \\
\hline & 1.627 & 1.581 & 1.588 & 1.622 & 1.547 & 1.591 & 1.681 & 1.649 & 1.684 & 1.538 & 1.523 & 1.544 & 1.527 & 1.721 & 1.575 & 1.526 & 1.580 \\
\hline ......... & .006 & .006 & .005 & .006 & .007 & .006 & .005 & .005 & .005 & .006 & .007 & .007 & .007 & .004 & .006 & .007 & .007 \\
\hline ............... & .002 & .002 & .006 & .001 & .003 & .003 & .003 & .002 & .002 & .002 & .001 & .001 & .001 & .002 & .002 & N.d. & .002 \\
\hline EVI & 1.999 & 2.006 & 2.006 & 2.002 & 1.991 & 2.000 & 1.997 & 2.022 & 1.990 & 1.995 & 2.005 & 2.004 & 1.984 & 2.000 & 2.008 & 2.014 & 2.008 \\
\hline $100 \times \mathrm{Mg}$ & & & & & & & & & & & 760 & 7 & 77.0 & 86.1 & 78.5 & 75.8 & 78 \\
\hline$\overline{\mathrm{Mg}+\mathrm{Fe}+\mathrm{Mn}}$ & 81 & & 79 & 8 & & & & & .7 & .2 & 76.0 & 77.1 & 87.0 & 86.1 & 78.0 & 75.8 & 78.8 \\
\hline
\end{tabular}

ROCK TYPE

[Rocks are classified by cumulus minerals listed in decreasing order of abundance and, in parentheses, by mode of all minerals]

\begin{tabular}{|c|c|}
\hline NUC-5-1678 & Olivine-chromite cumulate (wehrlite) \\
\hline 1038 & Olivine-chromite cumulate (peridotite) \\
\hline 784 & Olivine-bronzite-chromite cumulate (harzburgite) \\
\hline 426 & $\begin{array}{l}\text { Olivine-bronzite-chromite cumulate (plagioclase } \\
\text { harzburgite) }\end{array}$ \\
\hline NUC-2-1770 & Plagioclase-olivine cumulate (olivine gabbro) \\
\hline 1746 & Plagioclase-olivine cumulate (olivine gabbro) \\
\hline 1550 & Olivine-chromite cumulate (olivine gabbro) \\
\hline 1318 & Olivine-chromite cumulate (peridotite) \\
\hline 1122 & Olivine-chromite cumulate (dunite) \\
\hline 980 & Olivine-bronzite-chromite cumulate (harzburgite) \\
\hline
\end{tabular}

Olivine-bronzite-chromite cumulate (harzburgite)

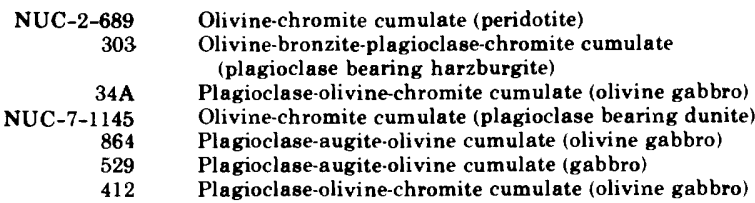

clase cumulate. There is no systematic relation between plagioclase anorthite content and olivine forsterite content, probably largely because postcumulus overgrowth is included in the analyses of the plagioclase.

Representative compositional zoning patterns for plagioclase, illustrated in figure 13 , show a common type of zoning wherein the core of the plagioclase grain is considerably less anorthite-rich than the rest of the grain. These cores generally have abrupt boundaries and are strongly embayed, indicating resorption. The cores of these grains are probably primocrysts that crystallized near the roof or walls of the magma chamber, where the magma temperature was depressed below the liquidus owing to conduction of heat by the enclosing rocks. Either by gravity settling or by convection, the primocrysts were carried into the hotter interior of the magma chamber, where they were partially resorbed, then eventually deposited on the floor of the chamber. The more anorthitic parts of the grains probably represent renewed higher temperature crystallization (relative to the temperature of crystallization at the roof) near the floor of the magma chamber.

\section{CHROMITE}

A total of 73 cumulus chromite grains from 13 samples were analyzed and the compositions in terms of the cation ratios $-\mathrm{Cr} /(\mathrm{Cr}+\mathrm{Al})$ and $\mathrm{Mg} /$ $\left(\mathrm{Mg}+\mathrm{Fe}^{+2}\right)$-were plotted in figure 14 ; selected analyses for each sample are given in table 6 . Individual grains may be chemically inhomogeneous, and there are large compositional differences from grain to grain in the same sample. The cation ratios of $\mathrm{Cr}$ to $\mathrm{Cr}+\mathrm{Al}$ and of $\mathrm{Mg}$ to $\mathrm{Mg}+\mathrm{Fe}^{+2}$ range from approximately 0.15 to 0.46 and 0.27 to 0.57 , respectively. $\mathrm{MnO}$ ranges from 0.1 to 0.4 percent (fig. 15), $\mathrm{TiO}_{2}$ from less than 0.1 percent to approximately 1.0 percent (fig. 16). Sample NUC-2-1770 contains a red and green chromian spinel; the green spinel is aluminum rich (table 6). The large range in composition of chromite grains in samples where the composition of olivine is essentially constant does not fit the theoretically determined equilibrium distribution of $\mathbf{M g}$ and $\mathrm{Fe}^{+2}$ between coexisting olivine and chromite (Irvine, 1965) and indicates that the olivine and chromite did not crystallize together. Enclosure of most of the cumulus chromite in olivine grains indicates that it 
Glacier) cumulates of the La Perouse layered gabbro

FeO. All minerals are cumulus|

\begin{tabular}{|c|c|c|c|c|c|c|c|c|c|c|}
\hline \multirow[b]{2}{*}{1271} & \multicolumn{10}{|c|}{ NUC-10 } \\
\hline & 1079 & 879 & 765 & 711 & 630 & 566 & 505 & 484 & 424 & 381 \\
\hline 39.9 & 39.5 & 38.6 & 38.3 & 37.2 & 38.2 & 37.8 & 37.9 & 38.8 & 38.9 & 40.1 \\
\hline 16.4 & 16.8 & 21.6 & 22.2 & 25.4 & 21.3 & 23.8 & 24.4 & 19.8 & 20.8 & 15.3 \\
\hline 44.0 & 43.4 & 39.6 & 38.2 & 35.7 & 38.9 & 37.1 & 37.0 & 40.8 & 40.0 & 44.4 \\
\hline .27 & .28 & .34 & .31 & .33 & .36 & .32 & .28 & .29 & .33 & .22 \\
\hline .11 & .06 & .12 & .10 & .10 & .07 & N.d. & N.d. & .06 & .06 & .04 \\
\hline 100.68 & 100.04 & 100.26 & 99.11 & 98.73 & 98.83 & 99.02 & 99.58 & 99.75 & 100.09 & 100.06 \\
\hline \multicolumn{11}{|c|}{ Cations per 4 oxygens - Continued } \\
\hline 1.001 & 1.000 & 0.998 & 1.00 & 0.99 & 1.002 & 1.00 & 0.999 & 1.000 & 1.003 & 1.006 \\
\hline .343 & .355 & .467 & .486 & .570 & .466 & .527 & .539 & .427 & .448 & .322 \\
\hline 1.647 & 1.637 & 1.526 & 1.495 & 1.427 & 1.521 & 1.466 & 1.456 & 1.566 & 1.538 & 1.660 \\
\hline .006 & .006 & .008 & .007 & .008 & .008 & .007 & .006 & .006 & .007 & .005 \\
\hline .002 & .001 & .002 & .002 & .002 & .002 & N.d. & N.d. & .001 & .001 & .001 \\
\hline 1.998 & 1.999 & 2.003 & 1.990 & 2.007 & 1.997 & 2.000 & 2.001 & 2.000 & 1.994 & 1.988 \\
\hline 5 & 1.9 & 76.3 & 75.2 & 71.2 & 76.2 & 73.3 & 72.8 & 78.3 & 77.2 & 83.6 \\
\hline
\end{tabular}

\footnotetext{
NUC-10-1271 Olivine-chromite cumulate (plagioclase bearing peridotite) Olivine-chromite cumulate (olivine gabbro)

Plagioclase-augite-olivine cumulate (olivine gabbro)

Plagioclase-olivine cumulate (olivine gabbro)

Plagioclase-olivine-bronzite cumulate (olivine gabbro)

Plagioclase-olivine cumulate (olivine norite)

Olivine-chromite cumulate (peridotite)

Plagioclase-a ugite-olivine cumulate (gabbro)

Olivine-plagioclase cumulate (plagioclase bearing dunite

harzburgite)

Plariourelivine cumulate (troctolite)

Olivine-chromite cumulate (plagioclase bearing wehrlite)
}

crystallized before olivine. This interpretation is consistent with the settling rate as predicted by Stoke's Law. The olivine crystals, being coarser, will settle faster than the finer but denser chromite crystals.

The compostions of the Brady Glacier chromite generally have $\mathrm{Al}>\mathrm{Cr}$ and $\mathrm{Fe}^{+2}>\mathrm{Mg}$; these compositions differ significantly from those reported for most other magmatic chromites. Continental stratiform intrusions, such as the Stillwater, Bushveld, and Muskox, generally have chromite that is chromium-rich $(\mathrm{Cr} /(\mathrm{Cr}+\mathrm{Al}), 0.5-0.85)$ (Irvine, 1967; Jackson, 1969; Cameron, 1978). Concentric-type ultramafic intrusions of southeastern Alaska also have chromium-rich chromite $(\mathrm{Cr} /(\mathrm{Cr}+\mathrm{Al}), 0.5-0.8)$ but are iron-rich $\left(\mathrm{Mg} /\left(\mathrm{Mg}+\mathrm{Fe}^{+2}\right), 0.35-0.6\right)$ (Irvine, 1967). Chromite in some mid-Atlantic Ridge and other midocean ridge basalts are aluminum-rich but are also magnesium-rich (Sigurdsson and Schilling, 1976). Chromites in ultramafic xenoliths in basalts (Aoki and Prinz, 1974; Basu and McGregor, 1975), in alpine-type peridotites (Irvine, 1967; Loney and others, 1971; Himmelberg and Loney, 1973; Dick, 1977), and in harzburgite tectonite of ophiolite complexes (Him-

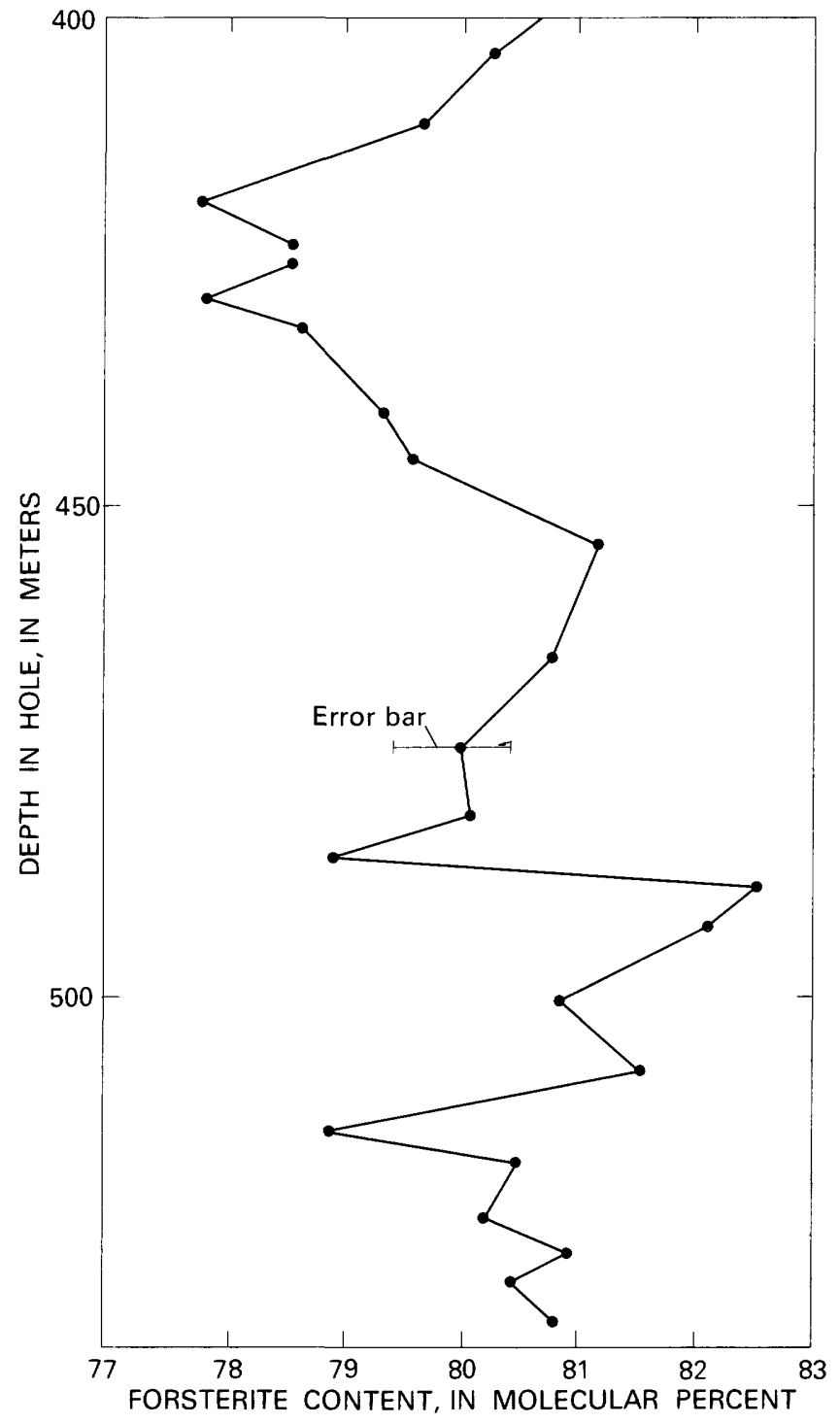

FIGURE 12.-Variation of olivine composition in the olivine cumulate in the lower part of core NUC-5. From G. K. Czamanske and L. C. Calk, (written commun., 1978).

melberg and Loney, 1980) may be aluminum-rich but are invariably also magnesium-rich and not magmatic. To our knowledge, the only chromites reported of composition similar to those in the Brady Glacier cumulates occur in the cumulate ultramafic rocks of the Canyon Mountain ophiolite, Oregon, $(\mathrm{Cr} /(\mathrm{Cr}+\mathrm{Al})$, 0.26-0.42; $\left.\mathrm{Mg} /\left(\mathrm{Mg}+\mathrm{Fe}^{+2}\right), 0.33-0.59\right)$ (Himmelberg and Loney, 1980).

In addition to the cumulus chromite in the ultramafic rocks, zoned chromium + iron chromite with cores containing as much as 53 percent $\mathrm{Cr}_{2} \mathrm{O}_{3}$ occurs in the massive sulfide. This chromite is believed to have crystallized directly from the immiscible sulfide melt (Czamanske and others, 1976). 


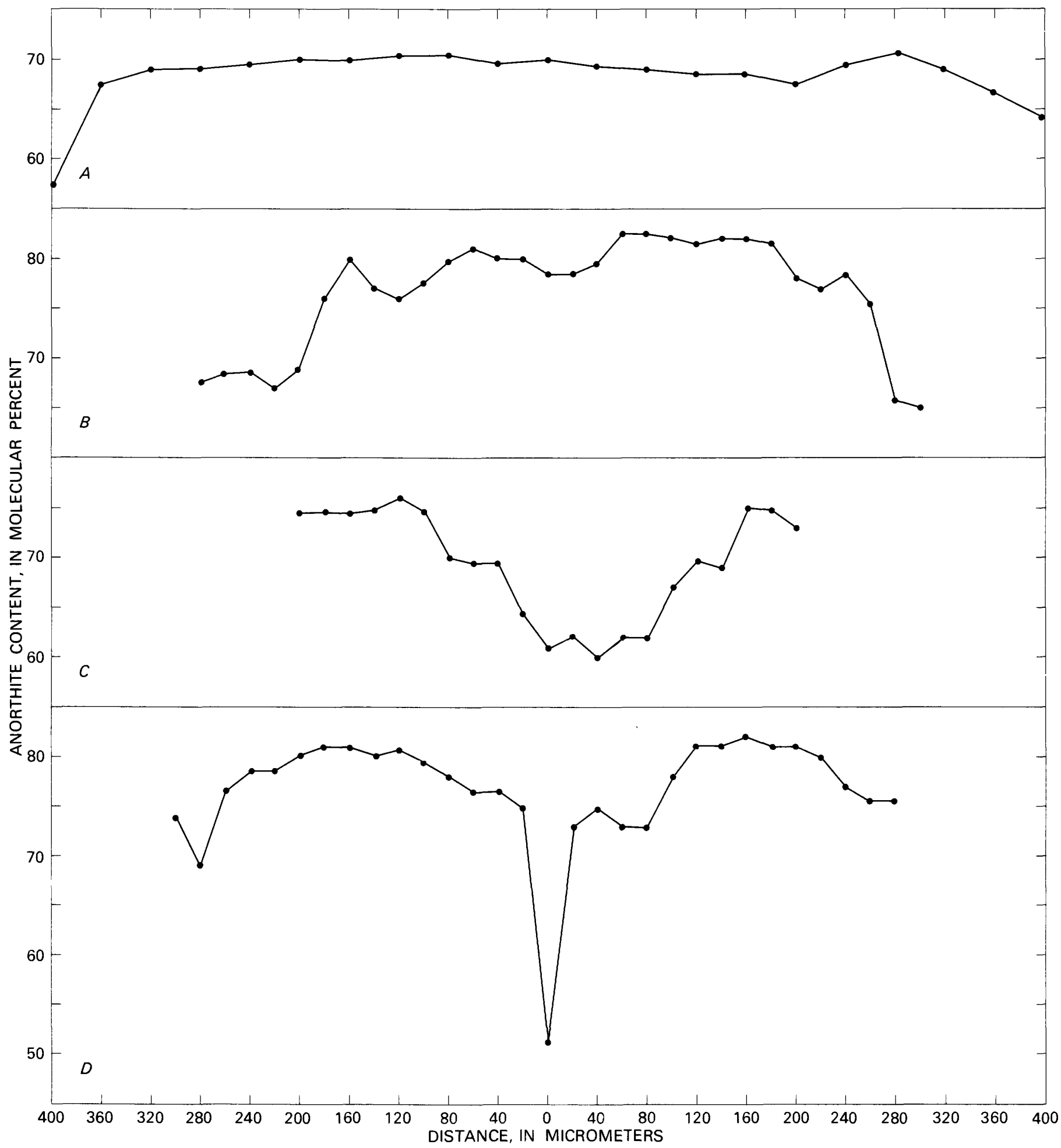

FIgURE 13 (above and facing page).-Composition profiles across plagioclase grains. $A$, Sample C-2-1746; $B$, Sample C-7-412; $C$, Sample C-7-529; D, Sample C-10-424; E, Sample C-10-484; F, Sample C-10-1430. 


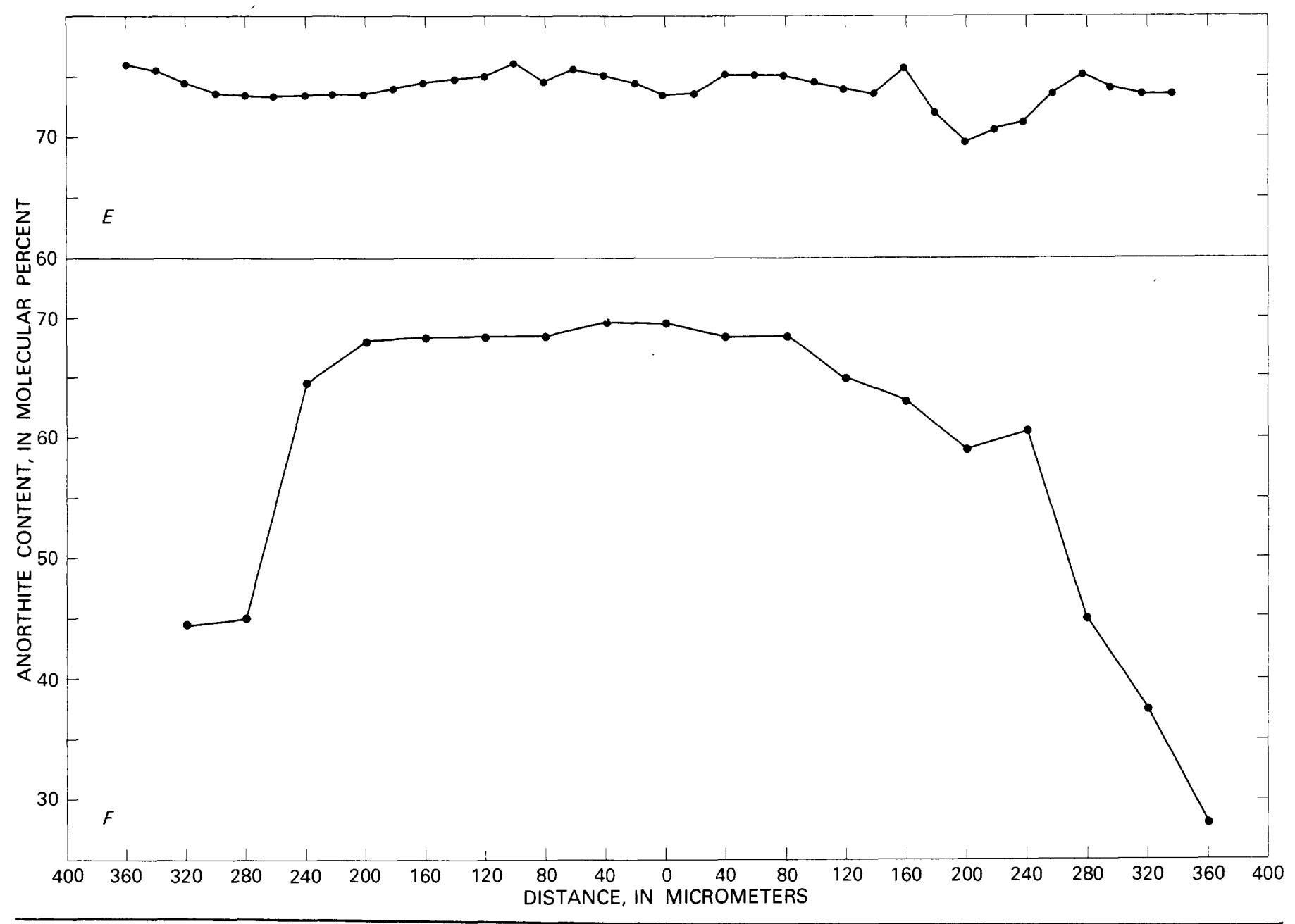

The composition of chromite should reflect the temperature, pressure, and fugacity of oxygen under which the chromite crystallized. Unfortunately, chromite chemistry as a function of these factors is not well known. It has been suggested that aluminous chromite reflects crystallization at relatively high pressures (Irvine, 1967; Haggerty, 1976), but variation in $\mathrm{Cr} / \mathrm{Al}$ has also been demonstrated to be a function of bulk composition (Irvine, 1967; Loney and others, 1971; Sigurdsson and Schilling, 1976). The composition of chromite coexisting with olivine is temperature dependent (Irvine, 1965), but unfortunately the olivine-chromite geothermometer developed by Jackson (1969) generally yields erroneous temperature values. (See, for example, Meyer and Boyd, 1972; Evans and Frost, 1975; Basu, 1977). Theoretical $f_{\mathrm{O}_{2}}$ isobars for chromian spinel coexisting with olivine and orthopyroxene have been calculated by Irvine (1965). Although the Brady Glacier chromites commonly occur only with olivine and probably were not in equilibrium with the silicate, calculation by Irvine's method suggests that they crystallized under a very low $f_{\mathrm{O}_{2}}$. A low $f_{\mathrm{O}_{2}}$ during crystallization is also indicated by the common occurrence of graphite throughout the Brady Glacier cumulates.

\section{CRYSTALLIZATION OF THE BRADY GLACIER CUMULATES}

The succession of cumulates underlying the Brady Glacier is believed to represent the early stages of fractional crystallization of the magma and deposition onto the floor of the magma chamber. Evidence for this includes: (1) the cumulus textures; (2) an order of crystallization of cumulus minerals similar 
TABLE 3.-Chemical composition and structural formulas of bronzite from the basal (Brady Glacier) cumulates of the La Perouse layered gabbro

\begin{tabular}{|c|c|c|c|c|c|}
\hline \multirow{2}{*}{$\begin{array}{l}\text { Drill core } \\
\text { Sample No. and } \\
\text { depth, in feet } \ldots \ldots\end{array}$} & \multicolumn{2}{|c|}{ NUC-5 } & \multicolumn{2}{|c|}{ NUC-2 } & \multirow{2}{*}{$\begin{array}{c}\text { NUC-10 } \\
711 \\
\end{array}$} \\
\hline & 784 & 426 & 980 & 303 & \\
\hline $\mathrm{SiO}_{2}$ & 53.8 & 53.9 & 54.2 & 54.3 & 52.8 \\
\hline$\ldots \ldots \ldots \ldots \ldots$ & 2.67 & 2.99 & 2.74 & 2.91 & 2.30 \\
\hline $\mathbf{T i O}_{2}$ & .19 & .17 & .20 & .18 & .25 \\
\hline $\mathrm{Cr}_{2} \mathrm{O}_{3} \ldots \ldots \ldots \ldots$ & .65 & .74 & .71 & .54 & .11 \\
\hline$\ldots \ldots \ldots \ldots . . .$. & 11.0 & 9.99 & 10.8 & 11.7 & 14.1 \\
\hline MnO & .20 & .18 & .23 & .24 & .28 \\
\hline MgO & 30.4 & 31.0 & 30.5 & 29.7 & 27.7 \\
\hline $\mathrm{CaO}$ & 1.46 & 1.59 & 1.56 & 1.35 & 2.11 \\
\hline $\mathrm{Na}_{2} \mathrm{O}$ & N.d. & .03 & .04 & .06 & .05 \\
\hline Total. & 100.37 & 100.59 & 101.98 & 8 & 99.70 \\
\hline
\end{tabular}

\begin{tabular}{|c|c|c|c|c|c|}
\hline \multicolumn{6}{|c|}{ Cations per 6 oxygens } \\
\hline $\mathbf{S i}$ & 1.903 & 1.894 & 1.905 & 1.911 & 1.911 \\
\hline Al(IV) & .079 & .106 & .095 & .089 & .089 \\
\hline$\Sigma T$ & 2.000 & 2.000 & 2.000 & 2.000 & 2.000 \\
\hline $\mathrm{Al}(\mathrm{VI})$ & .014 & .018 & .019 & .032 & .009 \\
\hline Ti & .005 & .004 & .005 & .005 & .007 \\
\hline $\mathrm{Cr}$ & .018 & .021 & .020 & .015 & .003 \\
\hline $\mathrm{Fe}^{+2}$ & .325 & .294 & .316 & .345 & .426 \\
\hline Mn & .006 & .005 & .007 & .007 & .009 \\
\hline $\mathbf{M g}$ & 1.603 & 1.626 & 1.596 & 1.560 & 1.495 \\
\hline $\mathrm{Ca}$ & .055 & .060 & .059 & .051 & .082 \\
\hline $\mathbf{N a} \ldots \ldots \ldots \ldots \ldots$ & N.d. & .002 & .003 & .004 & .004 \\
\hline$\Sigma \mathbf{M}$ & 2.026 & 2.030 & 2.025 & 2.019 & 2.035 \\
\hline $100 \times \mathrm{Mg}$ & 82.9 & 84.5 & 83.2 & 81.6 & 77.5 \\
\hline \multicolumn{6}{|l|}{$\overline{\mathrm{Mg}+\mathrm{Fe}+\mathrm{Mn}}$} \\
\hline $\begin{array}{l}\mathrm{Ca} \\
\mathbf{M g} \\
\mathbf{F e}\end{array}$ & $\begin{array}{r}2.79 \\
80.84 \\
16.37\end{array}$ & $\begin{array}{r}3.03 \\
82.13 \\
14.84\end{array}$ & $\begin{array}{r}2.98 \\
80.97 \\
16.05\end{array}$ & $\begin{array}{r}2.60 \\
79.74 \\
17.66\end{array}$ & $\begin{array}{r}4.08 \\
74.63 \\
21.29\end{array}$ \\
\hline
\end{tabular}

\section{ROCK TYPE}

[ Rocks are classified by cumulus minerals listed in decreasing order of abundance and, in parentheses, by mode of all minerals ]

$\begin{aligned} \text { NUC-5-784 } & \begin{array}{l}\text { Olivine-bronzite-chromite cumulate (harzburgite) } \\ \text { Olivine-bronzite-chromite cumulate (plagioclase bearing } \\ \text { harzburgite) }\end{array} \\ \text { NUC-2-980 } & \begin{array}{l}\text { Olivine-bronzite-chromite cumulate (harzburgite) } \\ \text { Olivine-bronzite-plagioclase-chromite cumulate (plagioclase } \\ \text { bearing harzburgite) }\end{array} \\ 303 & \begin{array}{l}\text { Plagioclase-olivine-bronzite cumulate (olivine gabbro) } \\ \text { NUC-10-711 }\end{array}\end{aligned}$

to that of other layered gabbros known to have originated by fractional crystallization and also similar to that expected from experimentally determined crystallization sequences of simple basaltic systems; and (3) a postcumulus phase that commonly becomes increasingly abundant upward prior to crystallizing as a cumulus phase. For example, postcumulus plagioclase becomes increasingly abundant in olivine cumulates below the olivine-plagioclase cumulates or the plagioclaseaugite-olivine cumulates. The crystallization of the magma was clearly complex: First, the cumulate sequences in the western and eastern parts of the area differ markedly (see fig. 4); this indicates that the liquid path of crystallization was different for the

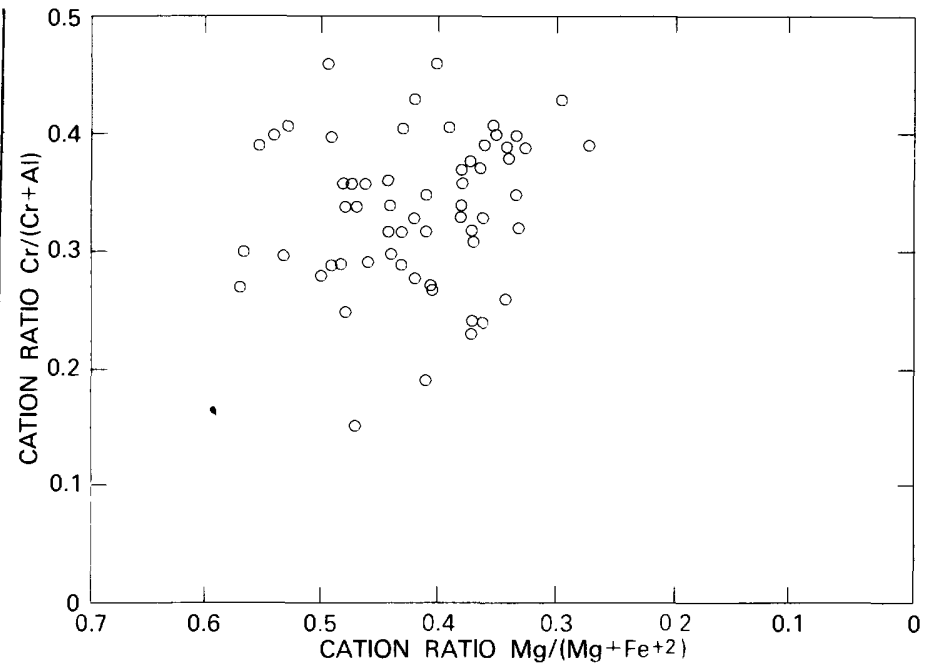

FIGURE 14.-Variation of chromite composition of the Brady Glacier cumulates in terms of the cation ratios $\mathbf{M g}$ to $\mathbf{M g}+$ $\mathrm{Fe}^{+2}$ and $\mathrm{Cr}$ to $\mathrm{Cr}+\mathrm{Al}$.

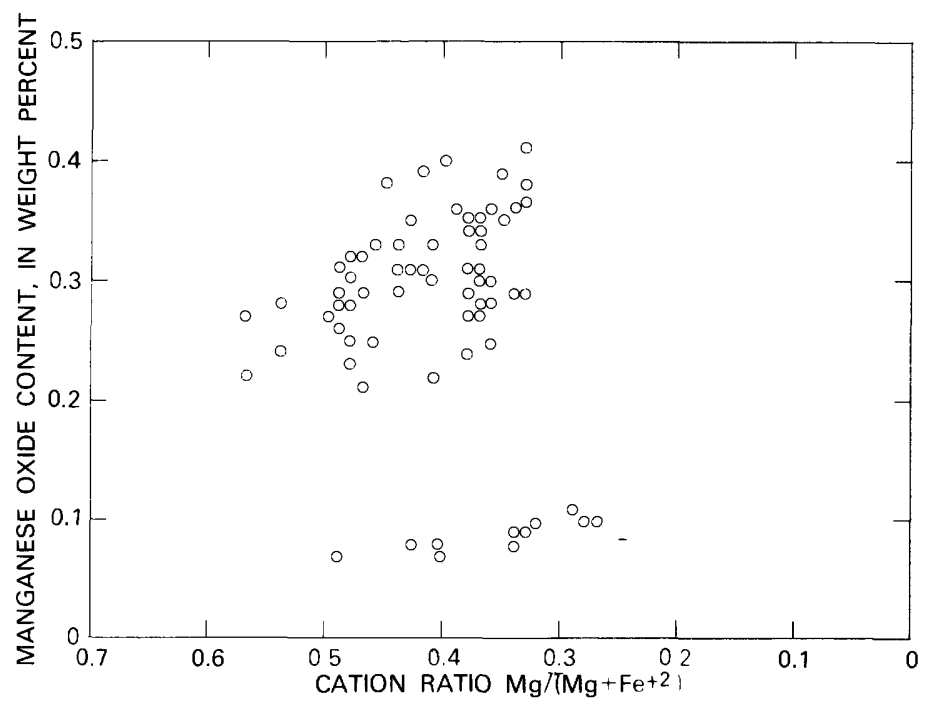

Figure 15.-Variation in MnO content of chromite in the Brady Glacier cumulates.

two areas. Secondly, not only are cumulate layers repeated, but continuous sequences proceeding from one-phase cumulates through two-phase cumulates to three-phase cumulates are generally absent. Instead, one-phase is commonly followed by the simultaneous crystallization of two additional cumulus phases, resulting in three-phase cumulates, and crystallization of one-phase cumulates is commonly repeated before a complete sequence is developed. Nevertheless, examination of the cumulates present allows interpretation of a general order of their crystallization.

The rock succession in the western part of the Brady Glacier cumulates is interlayered olivine cumulates, olivine-bronzite cumulates, and olivine- 
TABLE 4.-Chemical composition and structural formulas of augite from the basal (Brady Glacier) cumulates of the La Perouse layered gabbro

$[*$, asterisk, total iron as $\mathrm{FeO}]$

\begin{tabular}{|c|c|c|c|c|c|c|}
\hline \multirow{3}{*}{$\begin{array}{c}\text { Drill core } \\
\text { Sample No. and } \\
\text { d } \quad \text { feet.................. }\end{array}$} & \multicolumn{2}{|c|}{ NUC-2 } & \multirow{3}{*}{$\frac{\text { NUC-7 }}{864}$} & \multicolumn{3}{|c|}{ NUC-10 } \\
\hline & & & & & & \\
\hline & 1770 & 1746 & & 879 & 505 & 458 \\
\hline $\begin{array}{l}\mathrm{SiO}_{2} \\
\mathrm{Al}_{2} \mathrm{O}_{3} \\
\mathrm{TiO}_{2} \\
\mathrm{Cr}_{2} \mathrm{O}_{3} \\
\mathrm{FeO}^{*} \\
\mathrm{MnO} \\
\mathrm{MgO} \\
\mathrm{CaO} \\
\mathrm{Na}_{2} \mathrm{O}\end{array}$ & $\begin{array}{c}50.2 \\
6.03 \\
.61 \\
.98 \\
5.42 \\
.16 \\
16.4 \\
19.5 \\
.59 \\
\end{array}$ & $\begin{array}{c}51.0 \\
5.37 \\
.59 \\
1.06 \\
4.94 \\
.10 \\
16.8 \\
21.0 \\
.43\end{array}$ & $\begin{array}{c}52.3 \\
5.25 \\
.54 \\
.83 \\
5.72 \\
.14 \\
15.9 \\
20.4 \\
.47 \\
\end{array}$ & $\begin{array}{c}52.0 \\
4.60 \\
.45 \\
.59 \\
5.68 \\
.16 \\
16.0 \\
20.7 \\
.45 \\
\end{array}$ & $\begin{array}{c}52.7 \\
3.72 \\
.44 \\
.21 \\
5.90 \\
.17 \\
16.5 \\
20.2 \\
.40 \\
\end{array}$ & $\begin{array}{c}52.6 \\
4.13 \\
.55 \\
.54 \\
4.50 \\
.14 \\
15.6 \\
21.3 \\
.69 \\
\end{array}$ \\
\hline Total & 99.89 & 101.29 & 101.55 & 100.631 & 100.24 & 100.05 \\
\hline \multicolumn{7}{|c|}{ Cations per 6 oxygens } \\
\hline $\begin{array}{l}\mathrm{Si} \\
\mathrm{Al}(\mathrm{IV}) \\
\mathrm{\Sigma T} \\
\mathrm{Al}(\mathrm{VI}) \\
\mathrm{Ti} \\
\mathrm{Cr} \\
\mathrm{Fe}^{+2} \\
\mathrm{Mn}^{+2} \\
\mathbf{M g} \\
\mathrm{Ca} \\
\mathrm{Na} \\
\mathrm{\Sigma M}\end{array}$ & $\begin{array}{r}1.840 \\
.160 \\
2.000 \\
.101 \\
.017 \\
.028 \\
.166 \\
.005 \\
.894 \\
.766 \\
.042 \\
2.019\end{array}$ & $\begin{array}{r}1.846 \\
.154 \\
2.000 \\
.075 \\
.016 \\
.030 \\
.149 \\
.003 \\
.905 \\
.815 \\
.030 \\
2.023\end{array}$ & $\begin{array}{r}1.883 \\
.117 \\
2.000 \\
.106 \\
.015 \\
.024 \\
.172 \\
.005 \\
.853 \\
.787 \\
.033 \\
1.995\end{array}$ & $\begin{array}{r}1.894 \\
.106 \\
2.000 \\
.092 \\
.012 \\
.017 \\
.173 \\
.005 \\
.866 \\
.806 \\
.032 \\
2.003\end{array}$ & $\begin{array}{rr}4 & 1.921 \\
6 & .079 \\
0 & 2.000 \\
2 & .081 \\
2 & .012 \\
7 & .006 \\
3 & .180 \\
5 & .005 \\
6 & .896 \\
6 & .790 \\
2 & .029 \\
3 & 1.999\end{array}$ & 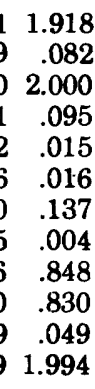 \\
\hline$\frac{100 \times \mathbf{M g}}{\mathrm{Mg}+\mathrm{Fe}+\mathrm{Mn}}$ & 83.9 & 85.6 & 82.8 & 83.0 & 82.9 & 85.7 \\
\hline $\begin{array}{l}\mathrm{Ca} \\
\mathbf{M g} \\
\mathbf{F e}\end{array}$ & $\begin{array}{r}41.94 \\
48.96 \\
9.10\end{array}$ & $\begin{array}{r}43.59 \\
48.41 \\
8.00\end{array}$ & $\begin{array}{r}43.43 \\
47.08 \\
9.49\end{array}$ & $\begin{array}{r}43.69 \\
46.93 \\
9.38\end{array}$ & $\begin{array}{r}42.34 \\
48.02 \\
9.64\end{array}$ & $\begin{array}{r}45.73 \\
46.72 \\
7.55\end{array}$ \\
\hline
\end{tabular}

ROCK TYPE

[Rocks are classified by cumulus minersls listed in decreasing order of abundance and, in parentheses, by mode of all minerals]

\begin{tabular}{|c|c|}
\hline NUC-2-1770 & $\begin{array}{l}\text { Plagioclase-olivine cumulate (olivine gabbro); analyzed augite } \\
\text { is postcumulus }\end{array}$ \\
\hline 1746 & $\begin{array}{l}\text { Plagioclase-olivine cumulate (olivine gabbro); analyzed augite } \\
\text { is postcumulus }\end{array}$ \\
\hline NUC-7-864 & Plagioclase-augite-olivine cumulate (olivine gabbro) \\
\hline NUC-10-879 & Plagioclase-augite-olivine cumulate (olivine gabbro) \\
\hline 505 & Plagnoclase-augite-olivine cumulate (gabbro) \\
\hline 458 & Plagioclase-augite cumulate (gabbro) \\
\hline
\end{tabular}

bronzite-plagioclase cumulates, all containing minor amounts of cumulus chromite. Excluding chromite, this succession suggests a general order of crystallization of olivine, olivine + bronzite, and olivine + bronzite + plagioclase. Since the boundary curve between olivine and orthopyroxene based on known liquidus phase relations at low pressures is a reaction curve (Andersen, 1915; Kushiro, 1972), olivine and orthopyroxene are not expected to crystallize simultaneously by simple fractional crystallization. The association of cumulus olivine and bronzite is relatively common in basal ultramafic rocks of some layered gabbros, for example, the Stillwater Complex, Montana (Jackson, 1961), the Great Dyke

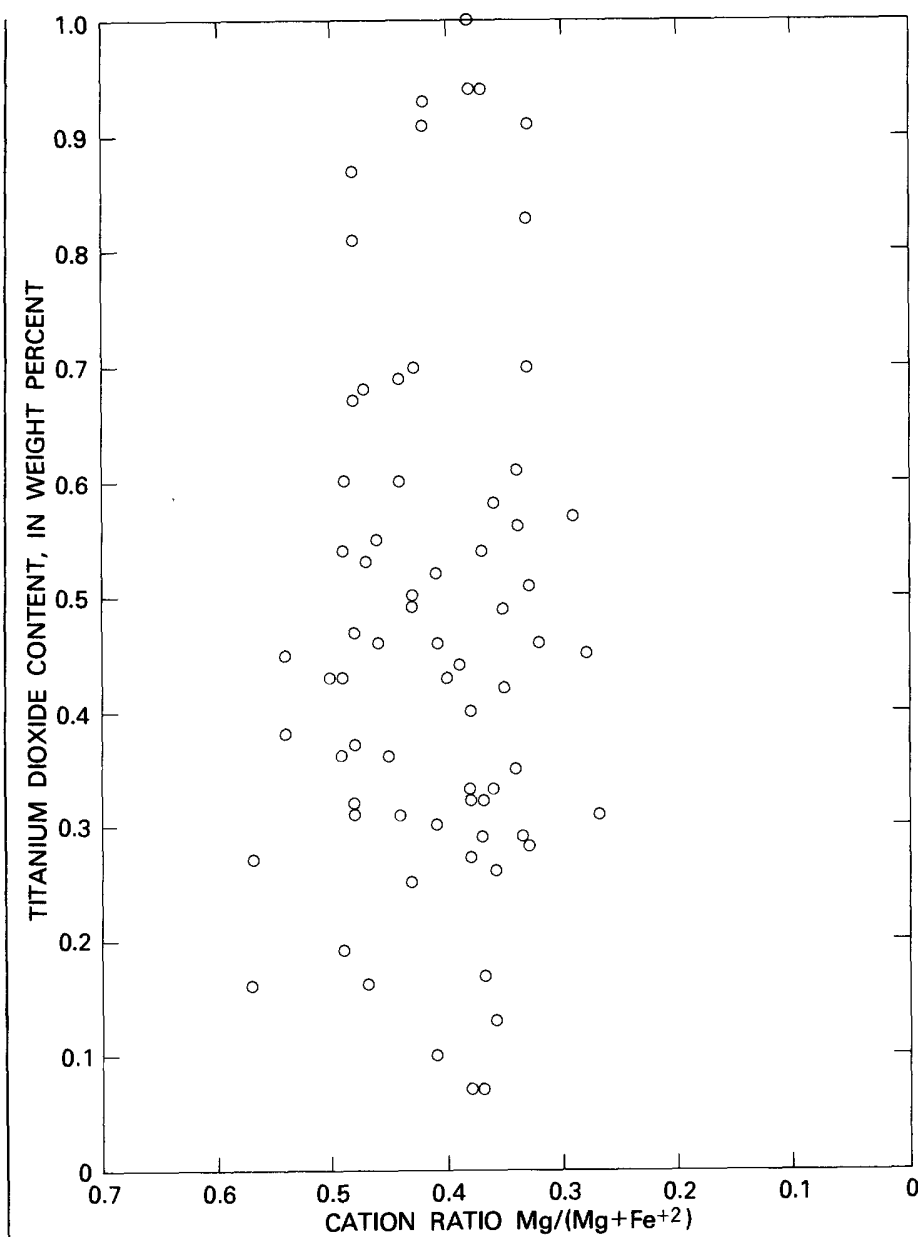

Figure 16.-Variation in $\mathrm{TiO}_{2}$ content of chromite in the Brady Glacier cumulates.

(Jackson, 1970), and the lower zone of the Bushveld Complex, South Africa (Cameron, 1978), where the crystallization order is olivine, olivine + bronzite, bronzite. The occurrence of olivine-bronzite cumulates could be explained by mechanical mixing (Irvine, 1970) or different crystallization levels for the olivine and bronzite (Jackson, 1961). Evidence for mixing is generally absent (Jackson, 1961; Irvine, 1970 ), and the similarity of the olivine-bronzite cumulates to olivine-augite cumulates of the Muskox intrusion led Irvine (1970) to propose that olivinebronzite cumulates are better explained by fractional crystallization. It is known that the incongruent melting of enstatite does not persist above about 5 kbar pressure in an anhydrous system (Boyd and others, 1964) and that it is eliminated by addition of iron to the system (Bowen and Schairer, 1935). Irvine (1970) proposed a phase diagram wherein at least a part of the olivine-orthopyroxene boundary curve is a cotectic and suggested that it might be obtained by a combination of pressure and composition effects. 
TABLE 5.-Chemical composition and structural formulas of plagioclase from the basal (Brady Glacier)cumulates of the La Perouse layered gabbro

[ N.d., not detected. *, asterisk, total iron as $\mathrm{FeO}$ ]

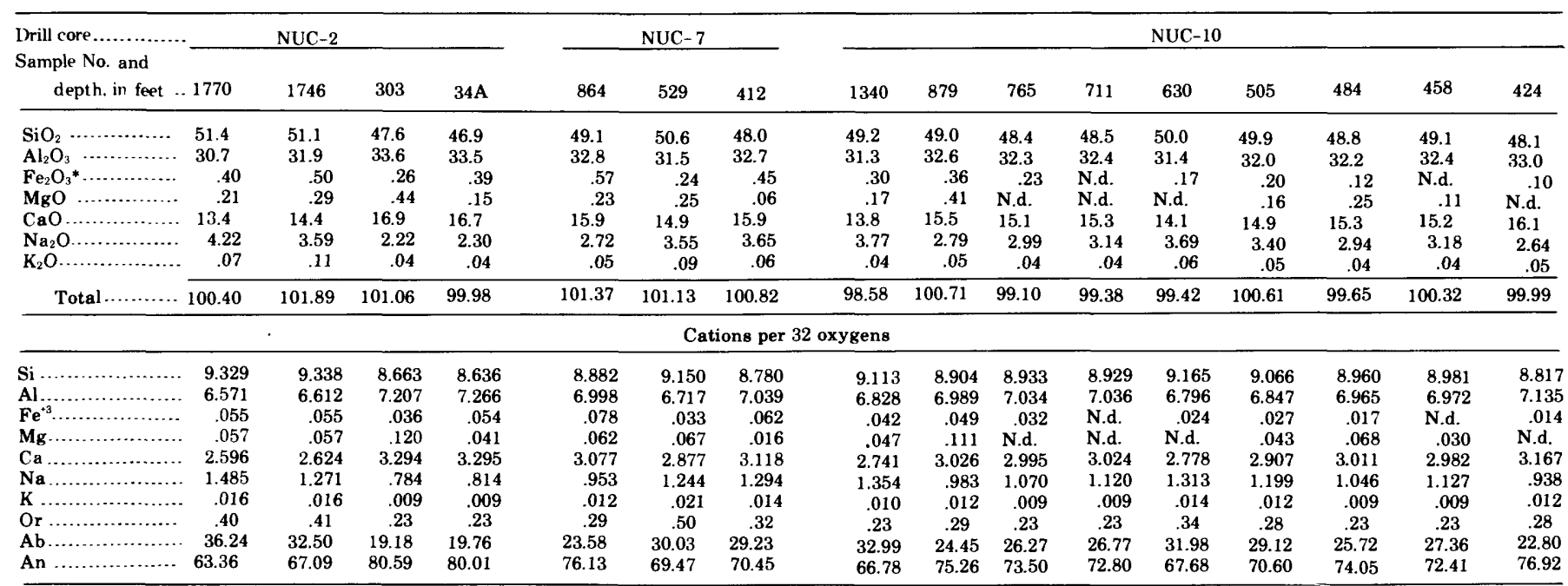

ROCK TYPE

[Rocks are classified by cumulus minerals listed in decreasing order of abundance and, in parentheses, by mode of all minerals]

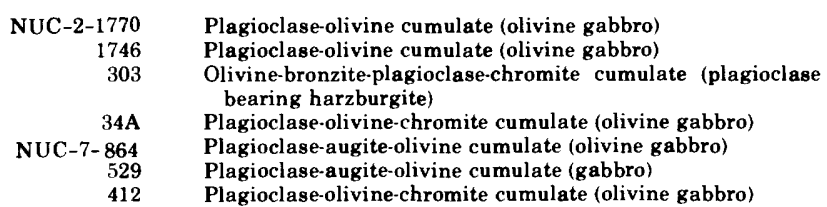

In the Brady Glacier cumulates, the crystallization of olivine + bronzite is followed by olivine + bronzite + plagioclase rather than bronzite alone; this progression suggests that the entire olivine-orthopyroxene boundary curve was a cotectic.

The eastern part of the Brady Glacier cumulates consists dominantly of olivine-chromite cumulates and plagioclase-augite-olivine cumulates. The common occurrence in these cumulates of plagioclaseolivine cumulates with or without chromite suggests that the sequence of crystallization was olivine + chromite, olivine + plagioclase with or without chromite, and olivine + plagioclase + augite. The crystallization order-olivine, plagioclase, augite-has been reported for the Rhum intrusion (Wager and Brown, 1968; Durnham and Wadsworth, 1978) and for oceanic tholeiites that crystallized at low pressures under anhydrous conditions (Tilley and others, 1972; Kushiro, 1973; Clague and Bunch, 1976; Bryan and others, 1976; Thompson and others, 1976; Bender and others, 1978). The absence of chromite in cumulates that contain augite is consistent with the reaction relation between chromite and clinopyroxene (Irvine, 1967; Dickey and others, 1971; Hill and Roeder, 1974). The order of crystallization as inter-

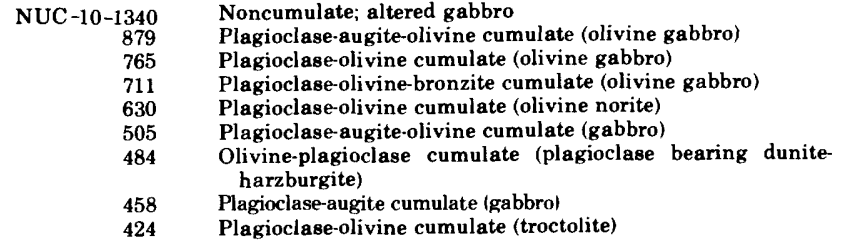

preted here assumes that the associated cumulus minerals crystallized and accumulated together. Although theoretical and experimental evidence suggests that plagioclase is generally less dense than the basaltic liquid from which it crystallized (Bottinga and Weill, 1970; Campbell and others, 1978), and therefore should have a tendency to float rather than settle with olivine or pyroxene, Irvine (1978) has demonstrated that plagioclase may be transported along with denser minerals to the bottom of the intrusion and deposited near or on the floor by magmatic currents.

The differences in crystallization sequences of the eastern and western parts of the Brady Glacier cumulates can be discussed using the qualitative olivine-clinopyroxene-plagioclase-silica tetrahedral phase-diagram model constructed by Irvine (1970). Both crystallization sequences originated in the olivine primary crystallization volume; the crystallization of the western cumulates then proceeded to the olivine-orthopyroxene boundary surface (presumably a cotectic in the natural system), and the crystallization of the eastern cumulates proceeded to the olivine-plagioclase cotectic. The two different crystallization sequences 
TABLE 6.-Chemical composition and structural formulas of chromite from the basal (Brady Glacier) cumulates of the La Perouse layered gabbro

[N.d., not detected. ", asterisk, Ferric and ferrous iron calculated from total iron by assuming an $\mathrm{RO} \mathrm{R}_{2} \mathrm{O}_{3}$ ratio of 1 to 1 and $\mathrm{Ti}$ present as $\mathrm{Fe}_{2} \mathrm{TiO} \mathrm{O}_{4}$ ]

\begin{tabular}{|c|c|c|c|c|c|c|c|c|c|c|c|c|c|c|c|c|c|}
\hline \multirow{2}{*}{$\begin{array}{l}\text { Drill core } \\
\text { Sample No. and } \\
\text { Jepth, in feet. }\end{array}$} & \multicolumn{4}{|c|}{ NUC-5 } & \multicolumn{9}{|c|}{ NUC-2 } & \multirow{2}{*}{$\frac{\text { NUC-7 }}{1145}$} & \multicolumn{3}{|c|}{ NUC -10} \\
\hline & 1678 & 1038 & 784 & 426 & $1770 \mathrm{r}$ & $1770 \mathrm{~g}$ & 1746 & 1550 & 1122 & 980 & 689 & 303 & $34 \mathrm{~A}$ & & 1271 & 1079 & 381 \\
\hline $\begin{array}{l}\mathrm{Cr}_{2} \mathrm{O}_{3} \ldots \ldots \ldots \ldots \\
\mathrm{Al}_{2} \mathrm{O}_{3} \ldots \ldots \ldots \ldots \ldots \\
\mathrm{Fe}_{2} \mathrm{O}_{3} * \ldots \ldots \ldots \ldots \\
\mathrm{TiO}_{2} \ldots \ldots \ldots \ldots \ldots \\
\mathrm{FeO} \ldots \ldots \ldots \ldots \ldots \ldots \\
\mathrm{MgO} \\
\mathrm{MnO}\end{array}$ & $\begin{array}{c}30.6 \\
33.7 \\
.58 \\
.54 \\
24.7 \\
8.10 \\
.35\end{array}$ & $\begin{array}{c}29.4 \\
32.6 \\
2.91 \\
.61 \\
25.6 \\
7.42 \\
.36\end{array}$ & $\begin{array}{c}27.3 \\
36.2 \\
.63 \\
.94 \\
24.7 \\
8.62 \\
.29\end{array}$ & $\begin{array}{c}30.5 \\
33.8 \\
.10 \\
.94 \\
24.9 \\
8.29 \\
.30\end{array}$ & $\begin{array}{c}26.7 \\
37.7 \\
.51 \\
.28 \\
26.4 \\
7.43 \\
.29\end{array}$ & $\begin{array}{c}13.4 \\
50.0 \\
1.68 \\
.16 \\
22.5 \\
11.2 \\
.21\end{array}$ & $\begin{array}{c}27.4 \\
36.9 \\
.87 \\
.93 \\
23.5 \\
9.62 \\
31\end{array}$ & $\begin{array}{c}27.0 \\
37.7 \\
1.36 \\
.49 \\
22.9 \\
9.85 \\
.35\end{array}$ & $\begin{array}{c}34.6 \\
30.4 \\
.05 \\
.91 \\
22.8 \\
9.11 \\
.39\end{array}$ & $\begin{array}{c}31.3 \\
32.5 \\
1.35 \\
.35 \\
25.6 \\
7.45 \\
.09\end{array}$ & $\begin{array}{c}32.9 \\
30.7 \\
.89 \\
.40 \\
27.6 \\
5.95 \\
.10\end{array}$ & $\begin{array}{c}31.0 \\
32.7 \\
1.28 \\
.46 \\
26.4 \\
7.05 \\
.10\end{array}$ & $\begin{array}{c}33.2 \\
32.6 \\
.52 \\
.50 \\
22.6 \\
9.57 \\
.08\end{array}$ & $\begin{array}{c}27.4 \\
36.2 \\
2.48 \\
.67 \\
21.2 \\
10.9 \\
.30\end{array}$ & $\begin{array}{c}28.1 \\
33.2 \\
5.00 \\
.60 \\
22.3 \\
9.75 \\
.33\end{array}$ & $\begin{array}{c}25.4 \\
41.7 \\
\text { N.d. } \\
.32 \\
21.5 \\
11.3 \\
.23\end{array}$ & $\begin{array}{r}30.5 \\
36.4 \\
\mathrm{~N} . \mathrm{d} . \\
.87 \\
21.0 \\
11.0 \\
.28\end{array}$ \\
\hline Total. & 98.57 & 98.90 & 98.68 & 98.83 & 99.31 & 99.15 & 99.53 & 99.65 & 98.26 & 98.64 & 98.54 & 98.99 & 99.07 & 99.15 & 99.28 & 100.45 & 10005 \\
\hline \multicolumn{18}{|c|}{ Cations per 32 oxygens } \\
\hline 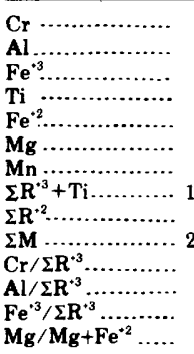 & $\begin{array}{r}5.935 \\
9.759 \\
.107 \\
.100 \\
5.063 \\
2.964 \\
.073 \\
15.901 \\
8.100 \\
24.001 \\
.376 \\
.617 \\
.007 \\
.369\end{array}$ & $\begin{array}{r}5.740 \\
9.492 \\
.542 \\
.113 \\
5.302 \\
2.735 \\
.075 \\
15.902 \\
8.112 \\
24.014 \\
.364 \\
.602 \\
.034 \\
.340\end{array}$ & $\begin{array}{r}5.223 \\
10.320 \\
.115 \\
.171 \\
5.000 \\
3.111 \\
.060 \\
15.829 \\
8.171 \\
24.000 \\
.334 \\
.659 \\
.007 \\
.384\end{array}$ & $\begin{array}{r}5.887 \\
9.749 \\
.018 \\
.173 \\
5.092 \\
3.019 \\
.062 \\
15.827 \\
8.173 \\
24.000 \\
.376 \\
.623 \\
.001 \\
.372\end{array}$ & $\begin{array}{r}5.091 \\
10.715 \\
.093 \\
.051 \\
5.318 \\
2.673 \\
.059 \\
15.950 \\
8.050 \\
24.000 \\
.320 \\
.674 \\
.006 \\
.334\end{array}$ & $\begin{array}{r}2.392 \\
13.270 \\
.285 \\
.027 \\
4.236 \\
3.750 \\
.040 \\
15.974 \\
8.026 \\
24.000 \\
.150 \\
.832 \\
.018 \\
.470\end{array}$ & $\begin{array}{r}5.157 \\
10.354 \\
.156 \\
.167 \\
4.686 \\
3.417 \\
.063 \\
15.834 \\
8.166 \\
24.000 \\
.329 \\
.661 \\
.010 \\
.422\end{array}$ & $\begin{array}{r}5.059 \\
10.524 \\
.242 \\
.087 \\
4.538 \\
3.479 \\
.070 \\
15.912 \\
8.087 \\
23.999 \\
.320 \\
.665 \\
.015 \\
.434\end{array}$ & $\begin{array}{r}6.779 \\
8.874 \\
.009 \\
.170 \\
4.722 \\
3.363 \\
.082 \\
15.832 \\
8.167 \\
23.999 \\
.433 \\
.566 \\
.001 \\
.416\end{array}$ & $\begin{array}{r}6.134 \\
9.483 \\
.252 \\
.065 \\
5.295 \\
2.752 \\
.019 \\
15.934 \\
8.066 \\
24.000 \\
.387 \\
.597 \\
.016 \\
.342\end{array}$ & $\begin{array}{r}6.560 \\
9.119 \\
.169 \\
.076 \\
5.817 \\
2.237 \\
.021 \\
15.924 \\
8.075 \\
23.999 \\
.414 \\
.575 \\
.011 \\
.278\end{array}$ & $\begin{array}{r}6.067 \\
9.524 \\
.238 \\
.086 \\
5.466 \\
2.598 \\
.021 \\
15.915 \\
8.085 \\
24.000 \\
.383 \\
.602 \\
.015 \\
.322\end{array}$ & $\begin{array}{r}6.381 \\
9.340 \\
.095 \\
.092 \\
4.605 \\
3.471 \\
.016 \\
15.908 \\
8.092 \\
24.000 \\
.403 \\
.591 \\
.006 \\
.430\end{array}$ & $\begin{array}{r}5.155 \\
10.158 \\
.444 \\
.120 \\
4.206 \\
3.859 \\
.060 \\
15.877 \\
8.125 \\
24.002 \\
.327 \\
.645 \\
.028 \\
.478\end{array}$ & $\begin{array}{r}5.376 \\
9.493 \\
.912 \\
.109 \\
4.522 \\
3.520 \\
.068 \\
15.890 \\
8.110 \\
24.000 \\
.341 \\
.602 \\
.057 \\
.438\end{array}$ & $\begin{array}{r}4.616 \\
11.285 \\
\text { N.d. } \\
.055 \\
4.131 \\
3.863 \\
.045 \\
15.956 \\
8.039 \\
23.995 \\
.290 \\
.710 \\
.000 \\
.483\end{array}$ & $\begin{array}{r}5.666 \\
10.100 \\
\mathbf{N . d} . \\
.154 \\
4.139 \\
3.848 \\
.050 \\
15.920 \\
8.043 \\
23.963 \\
.359 \\
.641 \\
.000 \\
.481\end{array}$ \\
\hline
\end{tabular}

\section{ROCK TYPE}

[Rocks are classified by cumulus minerals listed in decreasing order of abundance and, in parentheses, by mode of all minerals]

\begin{tabular}{|c|c|}
\hline NUC-5-1678 & Olivine-chromite cumulate (wehrlite) \\
\hline 1038 & Olivine-chromite cumulate (peridotite) \\
\hline 784 & Olivine-bronzite-chromite cumulate (harzburgite) \\
\hline 426 & $\begin{array}{l}\text { Olivine-bronzite-chromite cumulate (plagioclase) } \\
\text { bearing harzburgite) }\end{array}$ \\
\hline NUC-2-1770 & $\begin{array}{l}\text { Plagioclase-olivine cumulate (olivine gabbro) } \\
\text { r, red chromian spinel grain } \\
\text { g. green chromian spinel grain }\end{array}$ \\
\hline 1746 & Plagioclase-olivine cumulate (olivine gabbro) \\
\hline 1550 & Olivine-chromite cumulate (olivine gabbro) \\
\hline 1122 & Olivine-chromite cumulate (dunite) \\
\hline 980 & Olivine-bronzite-chromite cumulate (harzburgite) \\
\hline
\end{tabular}

imply either a lateral inhomogeneity of magma composition relative to the olivine-clinopyroxeneplagioclase-silica tetrahedron or different positions of the liquidus boundaries as a result of differences in total pressure, water fugacity, oxygen fugacity, compositional variables (such as the $\mathrm{An} / \mathrm{Ab}$ and $\mathrm{FeO}$ / $\mathrm{MgO}$ of the magma during fractional crystallization), or contamination by salic material. An increase in pressure (Green and Ringwood, 1976; Osborn, 1976 cited in Cameron, 1978), water fugacity (Yoder, 1965), and salic contamination (Irvine, 1975b) contracts the plagioclase crystallization volume and enhances the crystallization of pyroxene. The plagioclase volume is increased relative to pyroxene by an increase in the ratio of An to Ab (Irvine, 1970). Considering the close proximity and contiguous occurrence of the two cumulate sequences, differences in total pressure as a cause of the two different crystallization paths is extremely unlikely, and there are no mineralogical data to suggest differences in

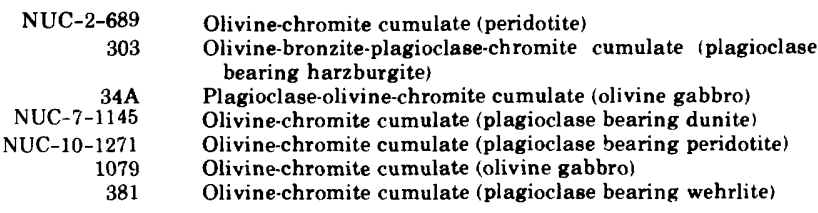

NUC-7-1145

NUC-10-1271

381

water fugacity or existence of contamination. The occurrence of graphite throughout the cumulates suggests that the oxygen fugacity was on the graphite- $\left(\mathrm{CO}+\mathrm{CO}_{2}\right)$ buffer during crystallization of both sequences.

If it is assumed that the conditions of crystallization and the liquidus boundaries for the two sequences were essentially the same, then their magmas are assumed to differ in composition. These differences need not be large if both compositions are near the 5-phase point olivine-orthopyroxene-plagioclase-clinopyroxene-liquid.

The repetition of the cumulate layers is similar to, but not so well developed as, the cyclic units described for other layered gabbros, such as the Stillwater, Bushveld, Great Dyke, Muskox, Rhum, and Jimberlana intrusions (Jackson, 1961, 1970; Wager and Brown, 1968; Irvine, 1970; Campbell, 1977). Two major models have been proposed to explain the origin of cyclic units: (1) periodic influx of undif- 
ferentiated magma (Cooper, 1936; Brown, 1956), and (2) bottom crystallization from a stagnant magma that is periodically replenished with fresh magma by variable depth convection (Jackson, 1961). A third model, order of nucleation of cumulus phases from a supercooled magma, was proposed for a particular type of layering in the Rhum and Bushveld intrusions but was not intended to have general application (Wager, 1959; Wager and Brown, 1968). In studying the Jimberlana intrusion, Campbell (1977) concluded that marked reversals in mineral chemistry and nickel-chromium whole-rock trends and zones of high-sulfide content at the base of cyclic units are probably indicative of multiple injection. Campbell noted that these features are absent from the cyclic units of the Great Dyke, Muskox, and Stillwater intrusions and therefore did not propose multiple injection as the sole process in forming cyclic units.

In the Brady Glacier cumulates, the parameters suggested to be indicative of multiple injection are not definitive. Sulfide mineralization occurs throughout the layered sequence and shows no correlation with rock type or stratigraphic position. Variations in mineral chemistry are not consistent; the olivine in the olivine-chromite cumulate at the top of core NUC-10 (fig. 10) does show a marked reversal in forsterite content, but the olivine in the olivinechromite cumulate at the 175-m level of core NUC-10 does not show a composition reversal. Further, in the olivine, olivine-bronzite layer sequence, olivine compositional variation in a single layer is as great as between layers. (Compare figs. 7 and 8 with fig. 14). Nevertheless, the repetition of cumulate layers, many of them relatively thin without good development of continuous fractionation sequences and the lateral inhomogeneity of the cumulate sequences, leads us to tentatively favor multiple injection of magma as a major process in producing the repetition of cumulate sequences in the Brady Glacier rock succession. This proposal is strengthened by examimation of the exposed La Perouse gabbro, which consists dominantly of interlayered olivine gabbro, norite, and gabbronorite but also contains thin layers of ultramafic rocks (olivine-chromite cumulates) throughout the sequence. Except for repetition of cumulate sequences, the La Perouse gabbro shows no systematic variation of mineral composition with stratigraphic height. This feature is best explained by frequent injection of magma, each batch at a different stage of fractionation at the time of injection and undergoing a different degree of fractionation before the next injection.

\section{METAMORPHIC COUNTRY ROCKS}

Metamorphic country rocks below the cumulates were penetrated in four drill holes; maximum penetration, approximately $30 \mathrm{~m}$, was in drill hole NUC2. The metamorphic rocks are fine to medium grained, generally have a well-developed foliation, and are dominantly biotite schists, hornblende-biotite schists, and cummingtonite-biotite schists. Limiting mineral assemblages containing the maximum number of coexisting phases are given below. Any combination of a smaller number of phases from the limiting assemblage is possible. All phases in an assemblage are interpreted to have formed in equilibrium.

1. Staurolite-garnet-cordierite-chlorite-biotite-plagioclase

2. Quartz-garnet-cordierite-chlorite-biotite-plagioclase

3. Quartz-garnet-anthophyllite-biotite-plagioclase

4. Sillimanite-cordierite-corundum-staurolite-plagioclase

5. Hornblende-cummingtonite-biotite-plagioclase

6. Quartz-cummingtonite-biotite-chlorite

In addition, all assemblages contain an opaque oxide mineral. Assemblages 2 and 3 occur in the same thin section, but anthophyllite does not occur with cordierite or chlorite.

The number of phases and components suggests that all assemblages formed under at least divariant conditions if not higher variance. The diagnostic association of garnet with cordierite as well as the occurrence of sillimanite and anthophyllite indicates that the metamorphic rocks formed under conditions of the upper amphibolite facies (Turner, 1968; Winkler, 1974). The association of cordierite with staurolite indicates that the rocks belong to the low-pressure, intermediate-type facies series of Miyashiro (1961), which is similar to Read's Buchan type (1952).

The common occurrence of cordierite + garnet in high-grade metamorphic rocks has prompted numerous experimental and theoretical investigations of the cordierite + garnet stability field (Reinhardt, 1968; Hess, 1969; Currie, 1971; Hensen and Green, $1971,1972,1973)$. The stability field as defined by the investigations is dependent on the presence of an additional phase, such as sillimanite, potassium feldspar, or hypersthene, phases not present in the schists of this study. Schreyer and Yoder (1964) 
investigated the stability of cordierite under hydrous conditions in the absence of other phases and found a temperature range of approximately $450^{\circ}-700^{\circ} \mathrm{C}$ for its formation. High-pressure breakdown for anhyrous cordierite has been calculated to be approximately $5.6 \mathrm{kbar}$ at $700^{\circ} \mathrm{C}$ (Newton and others, 1974); hydrous cordierite breaks down at pressures several kilobars higher (Newton, 1972).

The stability of staurolite was investigated by Richardson (1968) and by Ganguly (1968, 1972). Richardson's data require the presence of quartz and are not applicable to this study. Ganguly (1972) limited the field of staurolite stability without quartz between $520^{\circ}$ and $790^{\circ} \mathrm{C}$ at 5-kbar pressure and an oxygen fugacity in the middle of the magnetite field. The stability of anthophyllite has been investigated by Greenwood (1963). At a $P_{\mathrm{H}_{2} \mathrm{O}}$ of $1 \mathrm{kbar}$ in the presence of quartz, the lower stability limit of anthophyllite is approximately at $675^{\circ} \mathrm{C}$, the upper stability limit at $745^{\circ} \mathrm{C}$, where it breaks down to enstatite + quartz. At a $P_{\mathrm{H}_{2} \mathrm{O}}$ of $2 \mathrm{kbar}$, the field of stability of anthophyllite + quartz is $710^{\circ}-767^{\circ} \mathrm{C}$. In natural assemblages, the fields of both staurolite and anthophyllite would be more restricted.

In assemblage 4, the sillimanite, corundum, staurolite, and plagioclase occur enclosed in large cordierite porphyroblasts, also a part of assemblage 2 . This occurrence of sillimanite-cordierite-corundum-staurolite-plagioclase is mineralogically and texturally similar to the aluminous enclaves discussed by Robinson and Jaffe (1969), who explained the origin of such enclaves by a series of reactions involving anthophyllite (gedrite) + alumino-silicate to yield cordierite, corundum, and staurolite. Some similar reaction seems plausible for the origin of assemblage 4 , since it occurs in the same thin section with assemblages 2 and 3 . The presence of sillimanite gives a lower temperature limit of approximately $622^{\circ} \mathrm{C}$ using the data of Richardson and others (1969) and $501^{\circ} \mathrm{C}$ using the data of Holdaway (1971).

The temperatures indicated by the various phase equilibria for the formation of the metamorphic rocks underlying the Brady Glacier cumulates are compatible. The occurrence of anthophyllite + quartz is probably the best indication of the lower temperature limit and suggests that the temperature of meta.rorphism was greater than $675^{\circ} \mathrm{C}$ if $P_{\mathrm{H}_{2} \mathrm{O}}=P_{\text {total. }}$.

The regional metamorphic rocks exposed in the southern Fairweather Range are in the amphibolite facies but are of lower grade than the rocks recovered in the drill core. The exposed rocks contain garnetstaurolite assemblages; but garnet-cordierite assemblages are absent, and the aluminosilicate is andalusite rather than sillimanite. Rocks directly in contact with the La Perouse gabbro, however, are of higher grade, having assemblages containing garnet-cordierite, garnet-hypersthene, and sillimanite. These high-grade granulite-facies rocks occur as a rim or selvage of variable thickness around the gabbro and in abrupt contact with the lower grade regional metamorphic rocks; the maximum thickness of the higher grade rocks is approximately 200 $\mathrm{m}$. The metamorphic rocks below the Brady Glacier cumulates are probably equivalent to the higher grade metamorphic rocks exposed along the contact of the La Perouse gabbro.

Abruptness of the contact of the higher grade metamorphic rocks with the lower grade regional metamorphic rocks suggests that the La Perouse gabbro and the rim of high-grade metamorphic rocks were tectonically emplaced together into the lower grade terrane. It is not known whether the highgrade amphibolite-granulite-facies rocks represent a thermal aureole around the gabbro or reflect a regional high-grade terrane at a greater depth.

\section{SUMMARY}

The Brady Glacier ultramafic and gabbroic cumulates here described are the basal cumulates of the La Perouse layered gabbro. The most common rock types are olivine-chromite cumulate, olivine-bronzite-chromite cumulate, and plagioclase-augite-olivine cumulate. Individual cumulate layers are lenticular and wedge out in all directions over short distances. The contact of the cumulates with the underlying country rocks is irregular and has considerable relief.

Whole-rock chemical data indicate that the Brady Glacier ultramafic and gabboric rocks are related by differentiation and that olivine fractionation was the primary mechanism for derivation of the gabbro. Spatial distribution of cumulate sequences indicates two different orders of crystallization of cumulus silicate minerals: (1) olivine, bronzite, plagioclase and (2) olivine, plagioclase, augite. The differences in crystallization sequence are attributed to their formation by separate injections of magma of slightly different composition.

The Brady Glacier cumulates are the host rocks for nickel-copper sulfide deposits that consist of hexagonal and monoclinic pyrrhotite, pentlandite, and chalcopyrite. Although there is no correlation of sulfide mineralogy or abundance of disseminated sulfides with stratigraphic height or rock types; massive sulfide lenses do tend to occur along boundaries between mafic and ultramafic layers. Textural 
characteristics indicate that the sulfide mineralization represents an immiscible sulfide melt.

By Naldrett and Cabri's (1976) classification of ultramafic and related rocks, the La Perouse layered gabbro and sulfide deposit is closest to the "large stratiformly layered complexes." The La Perouse layered gabbro differs from other large stratiform intrusions in two ways: (1) The La Perouse body was not emplaced in a nonorogenic cratonic area but rather near a major fault system into country rocks that are similar to an oceanic crust assemblage; (2) there is no correlation between mineral chemical variation and stratigraphic height; this indicates frequent injection of magma batches rather than fractional crystallization of large volumes of magma.

\section{REFERENCES CITED}

Anderson, Olaf, 1915, The system anorthite-forsterite-silica: American Journal of Science, 4th Series, v. 39, p. 407-454

Aoki, Ken-ichiro, and Prinz, Martin, 1974, Chromian spinels in lherzolite inclusins from Itinomegata, Japan: Contributions to Mineralogy and Petrology, v. 46, p. 249-256.

Atkins, F. B., 1969, Pyroxenes of the Bushveld intrusion, South Africa: Journal of Petrology, v. 10, p. 222-249.

Basu, A. R., 1977, Olivine-spinel equilibria in lherzolite xenoliths from San Quintin, Baja, California: Earth and Planetary Science Letters, v. 33, p. 443-450.

Basu, A. R., and MacGregor, I. D., 1975, Chromite spinels from ultramafic xenoliths: Geochimica Cosmochimica Acta, v. 39, p. $937-945$.

Bender, J. F., Hodgen, F. N., and Bence, A. E., 1978, Petrogenesis of basalts from the project FAMOUS area: Experimental study from 0 th 15 kbars: Earth and Planetary Science Letters, v. 41, p. 277-302.

Bottinga, Yan, and Weill, D. F., 1970, Densities of liquid silicate systems calculated from partial molar volumes of oxide components: American Journal of Science, v. 269, p. 169-182.

Bowen, N. L., and Schairer, J. F., 1935, The system MgO$\mathrm{FeO}-\mathrm{SiO}_{2}$ : American Journal of Science, v. 29, p. 151-217.

Boyd, F. R., England, J. L., and Davis, B. T. C., 1964, Effects of pressure on the melting and polymorphism of enstatite, $\mathrm{MgSiO}_{3}$ : Journal of Geophysical Research, v. 69, p. 2101-2109.

Brew, D. A., Johnson, B. R., Grybeck, Donald, Griscom, Andrew, Barnes, D. F., Kimball, A. L., Still, J. C., and Rataj, J. L., 1978, Mineral resources of the Glacier Bay National Monument Wilderness study area, Alaska: U.S. Geological Survey OpenFile Report 78-494, $670 \mathrm{p}$

Brew, D. A., and Morrell, R. P., 1978, Tarr Inlet suture zone, Glacier Bay National Monument, Alaska, in K. M. Johnson, ed., The United States Geological Survey in Alaska: Accomplishments during 1977: U.S. Geological Survey Circular 772-B, p. B90-B92.

Brown, G. M., 1956, The layered ultrabasic rocks of Rhum, Inner Hebrides: Philosophical Transactions of the Royal Society of London, Series 13, v. 240, p. 1-53.

Bryan, W. B., Thompson, Geoffrey, Frey, F. A., and Dickey, J. S. 1976, Inferred geologic setting and differentiation in basalts from the Deep-Sea Drilling project: Journal of Geophysical Research, v. 81, p. 4285-4304.
Cameron, E. N., 1978, The lower zone of the Eastern Bushveld Complex in the Olifants River Trough: Journal of Petrology, v. 19 , p. 437-462.

Campbell, I. H., 1977, A study of macro-rhythmic layering and cumulate processes in the Jimberlana Intrusion, western Australia. Part I: The upper layered series: Journal of Petrology, v. 18 , p. $183-215$.

Campbell, I. H., Roeder, P. L., and Dixon, J. M., 1978, Plagioclase buoy ancy in basaltic liquids as determined with a centrifuge furnace: Contributions to Mineralogy and Petrology, v. 67, p. 369-377.

Clague, D. A., and Bunch, T. E., 1976, Formation of ferrobasalts at East Pacific Midocean spreading centers: Journal of Geophysical Research, v. 81, p. 4247-4256.

Cooper, J. R., 1936, Geology of the southern half of the Bay of Islands igneous complex: Newfoundland Department of $\mathrm{Na}$ tural Resources Geological Section Bulletin, v. 4, p. 1-62.

Currie, K. L., 1971, The reaction 3 cordierite $=2$ garnet +4 sillimanite +5 quartz, as a geological thermometer in the Opinicin Lake region, Ontario: Contributions to Mineralogy and Petrology, v. 33, p. 215-226.

Czamanske, G. K., Calk, L. C., Loney, R. A., and Himmelberg, G. R., 1978, Mineralization of the Crillon-La Perouse gabbro, southern Fairweather Range, Alaska [abs.]: Inernational Association on the Genesis of Ore Deposits Symposium, 5th Snowbird, Alta, Utah, 1978, Program and Abstracts, p. 79.

Czamanske, G. K., Himmelberg, G. R., and Goff, F. E., 1976, Zoned Cr, Fe-spinel from the La Perouse layered gabbro, Fairweather Range, Alaska: Earth and Planetary Science Letters, v. 33, p. 111-118.

Dick, H. J. B., 1977, Partial melting in the Josephine peridotite I, the effect on mineral composition and its consequence for geobarometry and geothermometry: American Journal of Science, v. 277, p. 801-832.

Dickey, J. S., Jr., Yoder, H. S., Jr., and Schairer, J. F., 1971, Chromium in silicate-oxide systems: Carnegie Institution of Washington Year Book 70, p. 118-122.

Dunham, A. C., and Wadsworth, W. J., 1978, Cryptic variation in the Rhum layered intrusion: Mineralogical Magazine, v. 42 , p. $347-356$.

Evans, B. W., and Frost, B. R., 1975, Chrome spinel in progressive metamorphism, a preliminary analysis: Geochimica et Cosmochimica Acta, v. 39, p. 955-972.

Ganguly, Jibamitra, 1968, Analysis of the stabilities of chloritoid and staurolite and some equilibria in the system $\mathrm{FeO}-\mathrm{Al}_{2} \mathrm{O}_{3}$ $\mathrm{SiO}_{2}-\mathrm{H}_{2} \mathrm{O}-\mathrm{O}_{2}$; American Journal of Science, v, 266, p. 277-298 1972, Staurolite stability and related paragenesis: Theory, experiments, and applications: Journal of Petrology, v. 13, p. $335-365$.

Green, D. H., and Ringwood, A. E., 1967, The genesis of basaltic magmas: Contributions to Mineralogy and Petrology, v. 15, p. $103-190$.

Greenwood, H. J., 1963, The synthesis and stability of anthophyllite: Journal of Petrology, v. 4, p. 317-351.

Haggerty, S. E., 1976, Opaque mineral oxides in terrestrial igneous rocks, in Douglas Rumble, 3d, ed., Oxide Minerals: Mineralogical Society of America Short Course Notes, v. 3, p. Hg101-Hg300.

Hensen, B. J., and Green, D. H., 1971, Experimental study of cordierite and garnet in pelitic compositions at high pressures and temperatures. 1, Compositions with excess aluminosilicate: Contributions to Mineralogy and Petrology, v. 33, p. $309-330$. 
1972, Experimental study of cordierite and garnet in pelitic compositions at high pressures and temperatures. 2, Compositions without excess alumino-silicates: Contributions to Mineralogy and Petrology, v. 35, p. 331-354.

1973, Experimental study of the stability of cordierite and garnet in pelitic compositions at high pressures and temperatures: Contributions to Mineralogy and Petrology, v. 38, p. 151-166.

Hess, H. H., 1960, Stillwater igneous complex, Montana, a quantitative mineralogical study: Geological Society of America Memoir 80, 230 p.

Hess, P. C., 1969, The metamorphic paragenesis of cordierite in pelitic rocks: Contributions to Mineralogy and Petrology, v. 24, p. 191-207.

Hill, Roderick, and Roeder, Peter, 1974, The crystallization of spinel from basaltic liquid as a function of oxygen fugacity: Journal of Geology, v. 82 , p. 709-729.

Himmelberg, G. R., and Loney, R. A., 1973, Petrology of the Vulcan Peak alpine-type peridotite, southwestern Oregon: Geological Society of America Bulletin, v. 84, p. 1585-1000

1980 , Petrology of the ultramafic and gabbroic rocks of the Canyon Mountain ophiolite, Oregon: American Journal of Science (E. D. Jackson memorial volume), v. 280A, p $232-268$

Holdaway, M. J. 1971, Stability of andalusite and the aluminum silicate phase diagram: American Journal of Science, v. 271, p. $97-131$.

Irvine, T. N., 1965, Chromian spinel as a petrogenetic indicatorPart 1, theory: Canadian Journal of Earth Sciences, v. 2, p. 648-672.

1967, Chromian spinel as a petrogenetic indicator-Part 2, petrologic applications: Can adian Journal of Earth Sciences, v. 4 , p. $71-103$.

1970, Crystallization sequence in the Muskox intrusion and other layered intrusions: 1, Olivine-pyroxene-plagioclase relations, in D. J. L. Visser, and G. von Gruenewaldt, eds. Symposium on the Bushveld igneous complex and other layered intrusions: Geological Society of South Africa Special Publication 1, p. 441-476.

1975a, Axelgold layered gabbro intrusion McConnell Creek map-area, British Columbia: Geological Survey of Canada Paper 75-1, part b, p. 81-88.

$1975 \mathrm{~b}$, Olivine-pyroxene-plagioclase relations in the system $\mathrm{Mg}_{2} \mathrm{SiO}_{4}-\mathrm{CaAl}_{2} \mathrm{Si}_{2} \mathrm{O}_{8}-\mathrm{KAlSi}_{3} \mathrm{O}_{8}-\mathrm{SiO}_{2}$ and their bearing on the differentiation of stratiform intrusions: Carnegie Institution of Washington Year Book 75, p. 492-500.

1978, Density current structure and magmatic sedimentation: Carnegie Institution of Washington Year Book 77, p. 717-725.

Irvine, T. N., and Smith, C. H., 1967, The ultramafic rocks of the Muskox intrusion, Northwest Territories, Canada, in P. J., Wyllie, ed., Ultramafic and related rocks: New York, John Wiley, p. 38-49.

IUGS Subcommission on the Systematics of Igneous rocks, 1973 Classification and nomenclature of plutonic rocks, recommendations: Neues Jahrbuch für Mineralogie Monatshefte, v. 4, p. 149-164.

Jackson, E. D., 1961, Primary textures and mineral associations in the ultramafic zone of the Stillwater Complex, Montana: U.S. Geological Survey Professional Paper 358, 106 p.

1967, Ultramafic cumulates in the Stillwater, Great Dyke and Bushveld intrusions, in P. J. Wyllie, ed., Ultramafic and related rocks: New York, John Wiley, p. 20-38.

1969. Chemical variations in coexisting chromite and olivine in chromitite zones of the Stillwater complex, in H. D. B.
Wilson, ed., Symposium on magmatic ore deposits: Ecomonic Geology Monograph 4, p. 41-71.

1970 , The cyclic unit in layered intrusions - a comparison of repetitive stratigraphy in the ultramafic parts of the Stillwater, Muskox, Great Dyke, and Bushveld complexes, in D. J. L. Visser and G. von Gruenewaldt, eds., Symposium on the Bushveld igneous complex and other layered intrusions: Geological Society of South Africa Special Publication 1, p. 391-424.

Jackson, E. D., Stevens, R. E., and Bowen, R. W., 1967, A computerbased procedure for deriving mineral formulas from mineral analyses: U.S. Geological Survey Professional Paper 575-C, p. C23-C31.

Kushiro, Ileuo, 1970, Determinations in liquidus relations in synthetic silicate systems with electron-probe analysis: The system forsterite-diopside-silica at 1 atmosphere: American Mineralogist, v. 57, p. 1260-1271.

1973, Origin of some magmas in oceanic and circum-oceanic regions: Tectonophysics, v. 17, p. 211-222.

Loney, R. A., Himmelberg, G. R., and Coleman, R. G., 1971, Structure and petrology of the alpine-type peridotite at Burro Mountain, California, U.S.A.: Journal of Petrology, v. 12, p. 245-309.

Maaløe, Sven, 1976, The zoned plagioclase of the Skaergaard intrusion, East Greenland: Journal of Petrology, v. 17, p. 398-419.

MacKevett, E. M., Jr., Brew, D. A., Hawley, C. C., Huff, L. C., and Smith, J. G., 1971, Mineral resources of Glacier Bay National Monument, Alaska: U.S. Geological Survey Professional Paper 632, $90 \mathrm{p}$.

Meyer, H. O. A., and Boyd, F. R., 1972, Composition and origin of crystalline inclusions in natural diamonds: Geochimica et Cosmochimica Acta, v. 30, p. 881-920.

Miyashiro, Akiho, 1961, Evolution of metamorphic belts: Journal of Petrology, v. 2, p. 277-311.

Naldrett, A. J., and Cabri, L. J., 1976, Ultramafic and related mafic rocks: Their classification and genesis with special reference to the concentration of nickel sulfides and platinum. group elements: Economic Geology, v. 71, p. 1131-1158.

Newton, R. C., 1972, An experimental determination of the highpressure stability limits of magnesium cordierite under wet and dry conditions: Journal of Geology, v. 80, p. 398-420.

Newton, R. C., Charles, T. V., and Kleppa, O. J., 1974, A calorimetric investigation of the stability of anhydrous magnesium cordierite with application to granulite facies metamorphism: Contributions to Mineralogy and Petrology, v. 44, p. 295-311.

Osborn, E. F., 1976, Origin of calc-alkali magma series of Santorini Volcano type in the light of recent experimental phaseequilibrium studies: International Congress on Thermal Waters, Geothermal Energy, and Volcanism of the Mediterranean Area, p. 22.

Page, N. J, 1977, Stillwater Complex, Montana: Rock succession, metamorphism, and structure of the complex and adjacent rocks: U.S. Geological Survey Professional Paper 999, 79 p.

Page, N. J, Shimek, Richard, and Huffman, Claude, Jr., 1972, Grain-size variations within and olivine cumulate, Stillwater Complex, Montana: U.S. Geological Survey Professional Paper 800-C, p. C29-C37.

Plafker, George, and MacKevett, E. M., Jr., 1970, Mafic and ultramafic rocks from a layered pluton at Mount Fairweather, Alaska: U.S. Geological Survey Professional Paper 700-B, p. B21-B26.

Read, H. H., 1952, Metamorphism and migmatisation in Ythan 
Valley, Aberdeenshire: Edinburgh Geological Society Transactions, v. 15 , p. $265-279$.

Reinhardt, E. W., 1968, Phase relations in cordierite-bearing gneisses from the Gananuque area, Ontario: Canadian Journal of Earth Sciences, v. 5, p. 455-482.

Richardson, S. W., 1968, Staurolite stability in a part of the system Fe-Al-Si-O-H: Journal of Petrology, v. 9, p. 467-488.

- Richardson, S. W., Gilbert, M. C., and Bell, P. M., 1969, Experimental determination of kyanite-andalusite and andalusitesillimanite equilibria; the aluminum silicate triple point: American Journal of Science, v. 267, p. 259-272.

Robinson, Peter, and Jaffe, H. W., 1969, Aluminus enclaves in gedrite-cordierite gneiss from southwestern New Hampshire: American Journal of Science, v. 267, p. 389-421.

Rossman, D. L., 1963, Geology and petrology of two stocks of layered gabbro in the Fairweather Range, Alaska: U.S. Geological Survey Bulletin 1121-F, $50 \mathrm{p}$.

Schreyer, Werner, and Yoder, H. S., Jr., 1964, The system Mgcordierite- $\mathrm{H} 2 \mathrm{O}$ and related rocks: Neues Jahrbuch Mineralogie, v. 101, p. 271-242.

Sigurdsson, Haraldur, and Schilling, J. G., 1976, Spinels in Mid-Atlantic Ridge basalts: Chemistry and occurrence: Earth and Planetary Science Letters, v. 29, p. 7-20.

Thompson, Geoffrey, Bryan, W. B., Frey, F. A., Dickey, J. S., and Suen, C. J., 1976, Petrology and geochemistry of basalts from DSDP Leg 34, Nazca Plate, in Initial Reports of the Deep Sea Drilling Project, V. 34: Washington, D.C., National Science Foundation, p. 215-226.

Tilley, C. E., Thompson, R. N., and Lovenburg, P. A., 1972, Melting relations of some oceanic basalts: Geological Journal, v. 8 , p. $59-64$.

Turner, F. J., 1968, Metamorphic petrology, mineralogical and field aspects: New York, McGraw-Hill, 403 p.

Visser, D. J. L., and G. von Gruenewaldt, eds., 1970, Symposium on the Bushveld Igneous Complex and other layered intrusions: Geological Society of South Africa Special Publication $1,763 \mathbf{p}$.

Wager, L. R., 1959, Differing powers of crystal nucleation as a factor producing diversity in layered igneous intrusions: Geological Magazine, v. 96, p. 75-80.

Wager, L. R., and Brown, G. M., 1968, Layered igneous rocks: Edinburgh, Oliver and Boyd, $588 \mathrm{p}$.

Wager, L. R., Brown, G. M., and Wadsworth, W. J., 1960, Types of igneous cumulates: Journal of Petrology, v. 1, p. 73-85.

Winkler, H. G. F., 1974, Petrogenesis of metamorphic rocks: New York, Springer-Verlag, 320 p.

Yoder, H. S., Jr., 1965, Diopside-anorthite-water at five and ten kilobars and its bearing on explosive volcanism: Carnegie Institution of Washington Year Book 64, p. 82-89. 